\title{
Salt marsh ecosystem restructuring enhances elevation resilience and carbon storage during accelerating relative sea-level rise
}

\author{
Meagan Eagle Gonneea ${ }^{a}, *$, Christopher V. Maio ${ }^{b}$, Kevin D. Kroeger ${ }^{\mathrm{a}}$, Andrea D. Hawkes ${ }^{\mathrm{c}}$, \\ Jordan Mora $^{\mathrm{d}}$, Richard Sullivan ${ }^{\mathrm{e}, \mathrm{g}}$, Stephanie Madsen ${ }^{\mathrm{e}}$, Richard M. Buzard ${ }^{\mathrm{b}}$, Niamh Cahill ${ }^{\mathrm{f}}$, \\ Jeffrey P. Donnelly \\ ${ }^{a}$ Woods Hole Coastal \& Marine Science Center, U.S. Geological Survey, 384 Woods Hole Rd, Woods Hole, MA 02543, USA \\ ${ }^{\mathrm{b}}$ University of Alaska Fairbanks, Department of Geosciences, PO Box 755780, Fairbanks, AK 99775, USA \\ ${ }^{\mathrm{c}}$ University of North Carolina Wilmington, Earth and Ocean Sciences Department, 601 South College Rd., Wilmington, NC 28403, USA \\ ${ }^{\mathrm{d}}$ Waquoit Bay National Estuarine Research Reserve, 131 Waquoit Highway, Waquoit, MA 02536, USA \\ ${ }^{\mathrm{e}}$ Woods Hole Oceanographic Institution, Coastal Systems Group, 266 Woods Hole Road, Mail Stop \#22, Woods Hole, MA 02543, USA \\ ${ }^{\mathrm{f}}$ University College Dublin, School of Mathematics and Statistics, Belfield, Dublin 4, Ireland \\ ${ }^{g}$ Texas A\&M University, Department of Oceanography, 400 Bizzell St, College Station, TX 77843, USA
}

\section{A R T I C L E I N F O}

\section{Keywords:}

Salt marsh

Sea-level rise

Carbon storage

Elevation

14-Carbon

Sea level index point

Accretion

\begin{abstract}
A B S T R A C T
Salt marshes respond to sea-level rise through a series of complex and dynamic bio-physical feedbacks. In this study, we found that sea-level rise triggered salt marsh habitat restructuring, with the associated vegetation changes enhancing salt marsh elevation resilience. A continuous record of marsh elevation relative to sea level that includes reconstruction of high-resolution, sub-decadal, marsh elevation over the past century, coupled with a lower-resolution 1500-year record, revealed that relative sea-level rose $1.5 \pm 0.4 \mathrm{~m}$, following local glacial isostatic adjustment $(1.2 \mathrm{~mm} / \mathrm{yr})$. As sea-level rise has rapidly accelerated, the high marsh zone dropped $11 \mathrm{~cm}$ within the tidal frame since 1932, leading to greater inundation and a shift to flood- and salt-tolerant low marsh species. Once the marsh platform fell to the elevation favored by low-marsh Spartina alterniflora, the elevation stabilized relative to sea level. Currently low marsh accretion keeps pace with sea-level rise, while present day high marsh zones that have not transitioned to low marsh have a vertical accretion deficit. Greater biomass productivity, and an expanding subsurface accommodation space favorable for salt marsh organic matter preservation, provide a positive feed-back between sea-level rise and marsh platform elevation. Carbon storage was $46 \pm 28 \mathrm{~g} \mathrm{C} / \mathrm{m}^{2} / \mathrm{yr}$ from 550 to $1800 \mathrm{CE}$, increasing to $129 \pm 50 \mathrm{~g} \mathrm{C} / \mathrm{m}^{2} / \mathrm{yr}$ in the last decade. Enhanced carbon storage is controlled by vertical accretion rates, rather than soil carbon density, and is a direct response to anthropogenic eustatic sea-level rise, ultimately providing a negative feedback on climate warming.
\end{abstract}

\section{Introduction}

Coastal salt marshes are vital transitional environments that provide key ecosystem services, including bird, fish, and animal habitat; storm surge and erosion protection; and climate benefits through long-term carbon storage (Chmura et al., 2003; Morgan et al., 2009; Narayan et al., 2017; Shepard et al., 2011). Complex feedbacks between ecology—plant production and decomposition—and geomorphology—sedimentation and erosion-have allowed globally extant salt marshes to maintain platforms within a narrow elevation range relative to sea level over thousands of years. However, they are vulnerable to coastal filling and development, declining sediment supply, eutrophication, and accelerating relative sea-level rise (Deegan et al., 2012; Gedan et al., 2009; Kirwan and Temmerman, 2009; Kroeger et al., 2017; Weston, 2014). Given this set of challenges, there remains a great deal of uncertainty regarding the capacity of salt marshes to persist in the Anthropocene under the predicted increases in the rate of global eustatic sea-level rise (SLR; 8-16 mm/yr by 2100 (IPCC, 2014)), and whether their long-term ability to store carbon and provide other ecosystem services will be diminished (Gedan et al., 2009).

While there is evidence in both experimental treatments and environmental records that marsh drowning is ongoing, other marshes are

\footnotetext{
* Corresponding author.

E-mail addresses: mgonneea@usgs.gov (M.E. Gonneea), cvmaio@alaska.edu (C.V. Maio), kkroeger@usgs.gov (K.D. Kroeger), hawkesa@uncw.edu (A.D. Hawkes), Jordan.mora@state.ma.us (J. Mora),rsullivan@whoi.edu, richardmsullivan@tamu.edu (R. Sullivan), smadsen@whoi.edu (S. Madsen), rmbuzard@alaska.edu (R.M. Buzard),niamh.cahill@ucd.ie (N. Cahill), jdonnelly@whoi.edu (J.P. Donnelly).
} 
transforming as salt- and flood-tolerant low marsh species replace shrinking high marsh ecosystems, and still others are keeping pace with relative sea level rise (Beckett et al., 2016; Crosby et al., 2016; Donnelly and Bertness, 2001; Kulawardhana et al., 2015; Smith, 2015; Watson et al., 2017). Indeed, a recent review suggests that marsh vulnerability has been overstated and that many marshes continue to aggrade (Kirwan et al., 2016a). Both the loss of salt marsh area and the ecological shift to dominance of low marsh species across the marsh platform has raised the question of whether these societally important ecological systems will remain viable in the future and whether they will continue to serve as important carbon stores (Chmura, 2013; Crosby et al., 2016; Holmquist et al., 2018a). In an effort to answer these questions, numerous models have attempted to determine marsh plant response to relative sea-level rise, as well as the associated change in marsh platform accretion capacity (i.e. elevation gain) (Langley et al., 2013; Voss et al., 2013), and to identify the threshold rate of relative sea-level rise under which salt marsh submergence occurs (Kirwan and Mudd, 2012; Morris and Bowden, 1986; Morris et al., 2002). Vegetation response to increased inundation occurs quickly, on the scale of seasons to years (Hanson et al., 2016; Langley et al., 2013; Watson et al., 2015), however the implications for long-term elevation resilience and carbon burial associated with this vegetation shift are not fully understood, particularly at the decadal and longer time scale.

This study was designed to evaluate how complex ecological feedbacks between relative sea level and habitat structure impact marsh elevation resilience in the face of rising sea levels. Our study was conducted in four fringing salt marshes in Cape Cod, MA, USA. Marsh transgression, where low marsh species move in to locations previously dominated by high marsh species, has been documented in these environments (Donnelly and Bertness, 2001; Smith, 2015). Prior to the recent acceleration in relative sea-level rise, these marshes kept pace with relative sea-level rise rates from $\sim 0.4 \mathrm{~mm} / \mathrm{yr}$ to $\sim 1 \mathrm{~mm} / \mathrm{yr}$ (Nerem et al., 2018; Orson and Howes, 1992; Redfield, 1972; Sallenger et al., 2012). Marshes such as those studied here, with low tidal amplitude and minimal external sediment supply, are predicted to be among the most vulnerable to sea-level rise, since accretion rates are limited to the maximum rate of organic matter preservation (Balke et al., 2016; Kearney and Turner, 2016). Thus, these systems may serve as a symbolic "canary in the coal mine" for coastal wetland fate under a regime of accelerating rates of relative sea-level rise.

In this study we first present evidence from seven annual vegetation surveys to determine if high marsh loss is occurring through low marsh vegetation transgression. We construct sediment records of elevation change over the past 1500 years from a series of nine sea level index points (SLIPs) derived from foraminifera assemblages in AMS (accelerator mass spectrometry) ${ }^{14} \mathrm{C}$ dated basal salt marsh peats, coupled with high temporal resolution ${ }^{210} \mathrm{~Pb}$ age models covering the past century at four microtidal salt marshes with low sediment supply. We hypothesize that the marsh platform will lower within the tidal frame as rates of relative sea-level rise outpace marsh accretion. Greater inundation will subsequently lead to low marsh vegetation transgression into former high marsh habitat, enhancing marsh productivity and accretion rates, and providing a positive feedback to sea-level rise and thus greater elevation resilience for the entire marsh complex. We further predict that if the marsh accretion rate keeps pace with relative sea-level rise, the environment conducive to organic matter preservation will expand, enhancing carbon storage.

\section{Materials and methods}

\subsection{Study area}

Our study was conducted in fringing salt marshes along the southern shore of Cape Cod, Massachusetts, USA within the Waquoit Bay estuarine system $\left(41.5^{\circ} \mathrm{N}, 70.5^{\circ} \mathrm{W}\right.$, Fig. 1$)$. Sand and gravel outwash deposited during the melting of the Laurentide Ice Sheet, which began its retreat approximately 23,000 years ago, was subsequently reworked by fluvial, coastal, and aeolian processes (Oldale, 1992; Uchupi et al., 1996). The reworked outwash, kettle basins, and spring sapping valleys provide the geologic framework for the back-barrier lagoon system (Gutierrez et al., 2003; Maio et al., 2014). It was not until the past 5000 years that sea-levels stabilized enough to allow for the widespread development of salt marshes on top of the reworked outwash sands of Waquoit (Orson and Howes, 1992).

Mixed semidiurnal micro-tides, with a mean range of $0.4 \mathrm{~m}$ (Fig. 2), protected locations within back-barrier lagoons, and the absence of large rivers, results in minimal sediment supply to these marshes. The current extent of the fringing salt marsh is discontinuous due to coastal development, which has rapidly expanded over the past 70 years. At present, the high marsh plant communities are dominated by Spartina patens, Juncus gerardii and Distichlis spicata, while Spartina alterniflora dominates the low marsh (Fig. 3) (Moseman-Valtierra et al., 2016). Salt marsh peat thickness is typically 1-2 m, although some sites (Hamblin Pond) have $>3 \mathrm{~m}$ of peat (Orson and Howes, 1992). The four marshes, Sage Lot Pond (SLP), Hamblin Pond (HP), Eel Pond (EP), and Great Pond (GP), included in this study vary in size and in density of residential development on their watersheds. Thus the associated estuaries exist along a nutrient-loading gradient $(0.5,2.9,6.3$ and $12.6 \mathrm{~g} \mathrm{~N}$ $\mathrm{m}^{-2} \mathrm{y}^{-1}$, Valiela et al. (2000)) (Fig. 1).

\subsection{Core collection and processing}

Sediment cores used for radiometric dating of salt marsh accretion over the past century were collected from each of the four fringing marshes in 2013 and 2014 ( 3 in SLP, 3 in HP, 2 in EP and 3 in GP, Fig. 1, Table S1). For the 11 cores collected for ${ }^{210} \mathrm{~Pb}$ dating, the plastic core liner (diameter $11 \mathrm{~cm}$ ) was fitted with a gasketed piston that was placed on the sediment surface. The clear, sharpened core liner was pushed down into the marsh subsurface, while tension on the piston maintained it at the marsh surface. We visually observed the sediment surface to ensure that the soil column did not compact during collection. Once the core reached the underlying coarse sediment interface (except at HP, where the depth to the peat base was $>2 \mathrm{~m}$ ), the core liner and piston were removed from the marsh with a pulley system. Total peat recovered ranged from 14 to $150 \mathrm{~cm}$ using this system. The cores were split vertically, sampled at $1 \mathrm{~cm}$ intervals to $30 \mathrm{~cm}$ below soil surface and $2 \mathrm{~cm}$ intervals thereafter, frozen, and then freeze-dried. Dry bulk density was determined from the weight of the sediment section of known volume after freeze-drying to constant weight.

A series of 18 additional cores were collected at SLP to capture the subsurface contact between overlying high marsh peat and underlying outwash sand, representing salt marsh transgression (Fig. 1, Table 1). Cores were collected along a seaward to landward transect at nine locations approximately $3-5 \mathrm{~m}$ apart using a Russian peat corer to limit compaction at sites that are currently in the low marsh but were previous locations of the high marsh boundary (Fig. 1). Duplicate overlapping cores were collected to ensure preservation of the basal contact. The cores were transported to the lab in PVC casing and refrigerated at $7^{\circ} \mathrm{C}$.

\subsection{Short-lived radiometric dating}

Approximately $5 \mathrm{~g}$ of dried peat was homogenized and placed on a planar-type gamma counter for $24-48 \mathrm{~h}$ to measure ${ }^{7} \mathrm{Be},{ }^{137} \mathrm{Cs},{ }^{210} \mathrm{~Pb}$, and ${ }^{226} \mathrm{Ra}$ at $477,661.6,46.5$ and $352 \mathrm{KeV}$ energies respectively (Canberra Inc., USA). Detector efficiency was determined from the U.S. Environmental Protection Agency standard pitchblende ore in the same geometry as the samples. Activities of ${ }^{7} \mathrm{Be},{ }^{137} \mathrm{Cs}$, and ${ }^{210} \mathrm{~Pb}$ were decay corrected to time of collection. Suppression of low energy peaks by selfabsorption was corrected for (Cutshall et al., 1983). Detection limit for excess ${ }^{210} \mathrm{~Pb}$ was $0.05 \mathrm{dpm} \mathrm{g}^{-1}$. A $0.5 \mathrm{~g}$ aliquot of sediment was further ground in a ball mill and then analyzed for carbon (C) concentration 


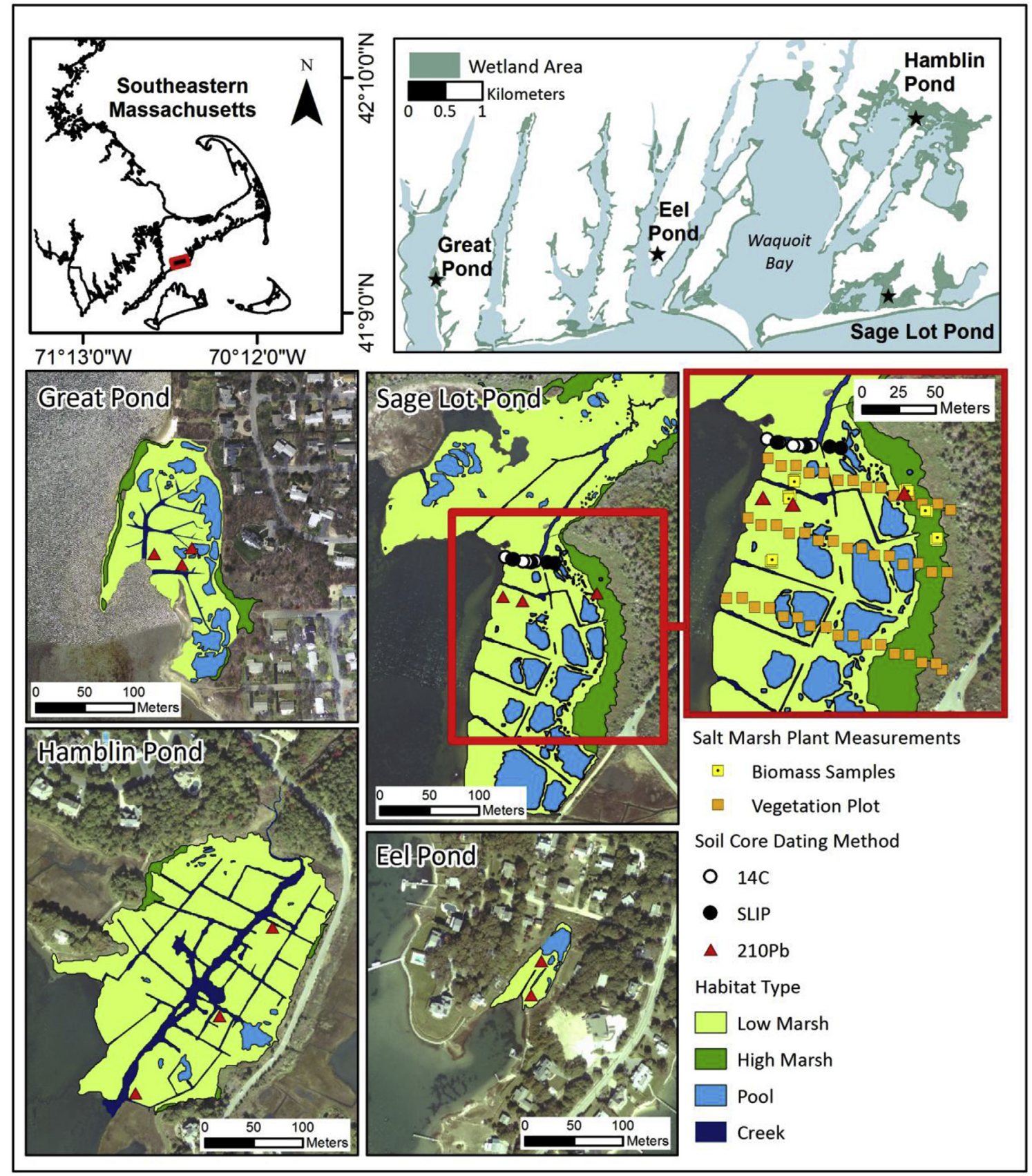

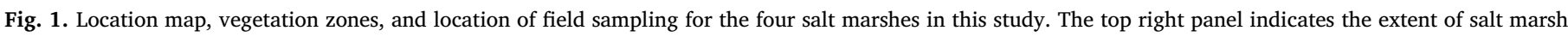

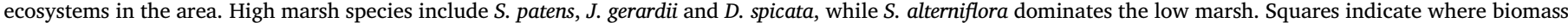

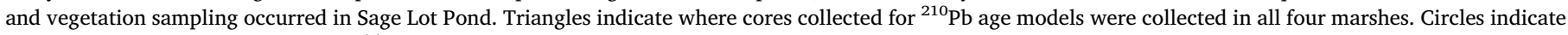
locations of basal peat collection for ${ }^{14} \mathrm{C}$ age dating.

and $\delta^{13} \mathrm{C}$ at the U.C. Davis Stable Isotope Facility with an Elementar Vario EL Cube or Micro Cube elemental analyzer (Elementar Analysensysteme, Germany) interfaced to a PDZ Europa 20-20 isotope ratio mass spectrometer (Sercon Ltd., UK).

Sediment ages and accretion rates for the past century were calculated with the continuous rate of supply ${ }^{210} \mathrm{~Pb}$ age model, a variant on the advection-decay equation (Appleby and Oldfield, 1978). This model assumes that ${ }^{210} \mathrm{~Pb}$ supply to the sediment surface is constant through time, but allows for changing sedimentation rates, in addition to decay, to control the down-core activity of ${ }^{210} \mathrm{~Pb}$. Thus, this model was used to provide sufficient temporal resolution to assess decadal scale changes over the past century in these marshes. The common form of the continuous rate of supply model as derived by Appleby and Oldfield (1978) solves for age $t$ based on the distribution of ${ }^{210} \mathrm{~Pb}$ in the sediment record. Prior to application of the age model, ${ }^{210} \mathrm{~Pb}$ profiles were evaluated to ensure they were sufficiently resolved to apply the continuous rate of supply model without bias towards ages that are too old or accretion rates that are too low at depth (Binford, 1990).

\subsection{Radiocarbon dating}

Plant macrofossils were sampled at the sandy peat transition zone between the basal sand and continuous peat, typically between 1 and $8 \mathrm{~cm}$ above the actual basal contact as observed in core logs. Assuming the basal peat sampled represents the establishment of the high marsh surface at the sampled elevation, and that there is limited peat 

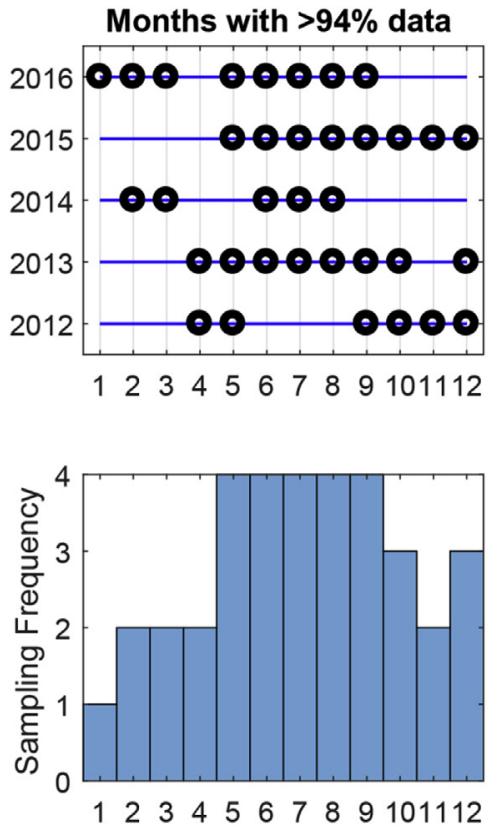

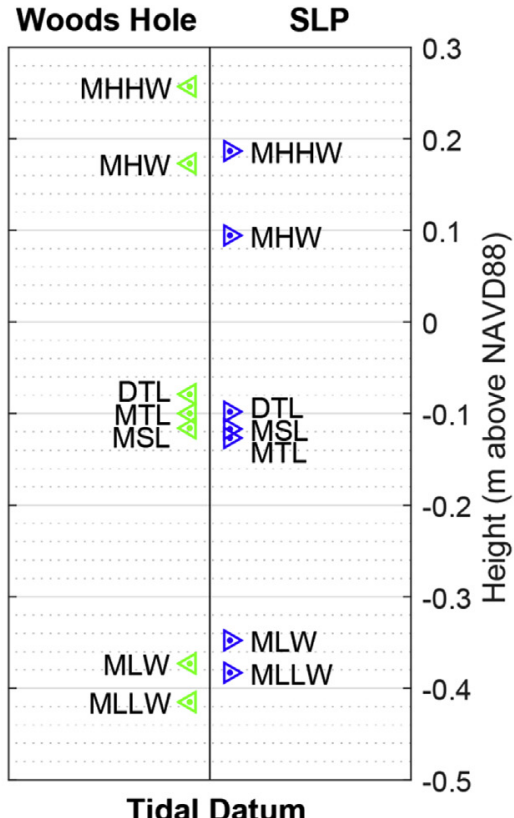

Fig. 2. (Right) Tidal datums corrected for Sage Lot Pond (SLP, blue) based on nearby Woods Hole NOAA station 8,447,930 (green) for the 1983-2001 National Tidal Datum Epoch. (Left) Monthly means are used when calculating tidal datums, but lapses in data collection led to gaps in sampling. Only months with 95\% data collection were used, and each month was sampled at least once over the six-year period.
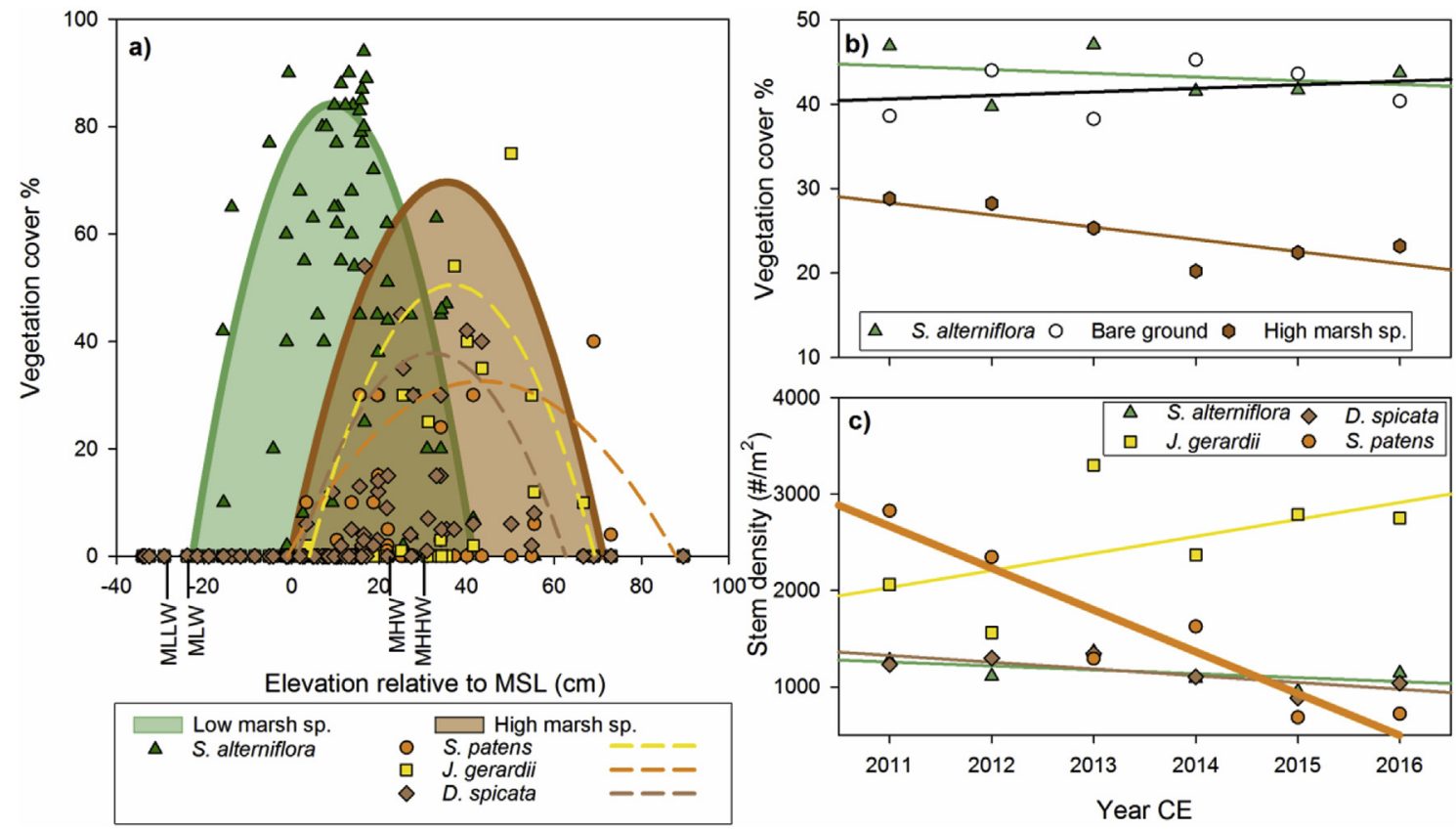

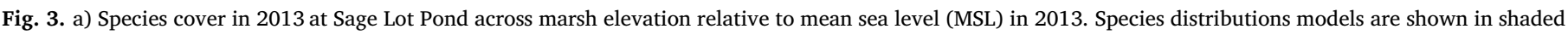

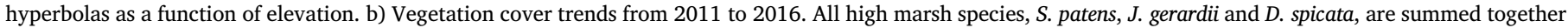

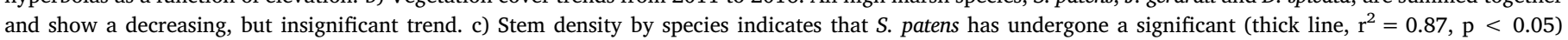
reduction over the 6 years. $J$. gerardii density has increased, but not significantly $\left(r^{2}=0.29, p=0.27\right)$.

compression at the basal contact, its ${ }^{14} \mathrm{C}$ age and sampled elevation can be used as a proxy for the paleo-high marsh surface (Engelhart and Horton, 2012; Hawkes et al., 2016). Rhizomes, which grow directly below the marsh surface, belonging to the high marsh species $S$. patens, $J$. gerardii and $D$. spicata, were identified based on the key provided by Niering et al. (1977), cleaned with deionized water, and subsampled under a dissecting microscope. Seventeen samples were submitted to the National Ocean Science Accelerator Mass Spectrometry facility at the Woods Hole Oceanographic Institution for ${ }^{14} \mathrm{C}$ AMS dating. All organic-derived ${ }^{14} \mathrm{C}$ ages were calibrated using Calib version 7.0.1 with the IntCal13 calibration data set (Reimer et al., 2009) and are here reported in median calibrated years before present and median calibrated years with a 2 sigma $(2 \sigma)$ range of uncertainty.

\subsection{Foraminifera sampling and relative sea-level reconstruction}

Basal peat cores were processed for foraminiferal analysis by first identifying the basal stratigraphic contact between Pleistocene sand and overlying initial salt marsh development assumed to be high marsh peat. Iterative sampling from the contact up-core was done until foraminifera were of sufficient abundance to reasonably determine that the assemblages were in situ. Foraminiferal sediment samples $\left(2 \mathrm{~cm}^{3}\right)$ were sieved through 500 and $63 \mu \mathrm{m}$ sieves to isolate foraminiferal bearing sediments and avoid clays, silts, and larger organics. Dead 
Table 1

\begin{tabular}{|c|c|c|c|c|c|c|c|c|c|c|c|}
\hline Lab No. & Latitude ${ }^{\circ} \mathrm{N}$ & Longitude ${ }^{\circ} \mathrm{W}$ & $\begin{array}{l}\text { Depth in } \\
\text { Core }(\mathrm{cm})\end{array}$ & $\begin{array}{l}\text { Depth } \\
\text { NAVD88 } \\
(\mathrm{cm})\end{array}$ & ${ }^{14} \mathrm{C}$ Age (years) & $\begin{array}{l}2 \sigma \text { cal BP Median } \\
\text { Prob. (years) }\end{array}$ & $\begin{array}{l}2 \sigma \text { cal AD Median } \\
\text { Prob. (years) }\end{array}$ & $\delta^{13} \mathrm{C} \% 0$ & $\Delta^{14} \mathrm{C}$ & $\begin{array}{c}\text { Material } \\
\text { Dated }\end{array}$ & RSL Point \\
\hline OS-109781 & 41.55479 & -70.5065 & 34 & -18 & $100 \pm 25$ & $110 \pm 32$ & $1840 \pm 32$ & -11.9 & -19.87 & S. patens & SLIP \\
\hline OS-109782 & 41.55479 & -70.5065 & 40 & -24 & $190 \pm 20$ & $178 \pm 37$ & $1772 \pm 37$ & -25 & -30.6 & S. patens & SLIP \\
\hline OS-109957 & 41.5548 & -70.5066 & 43 & -29 & $180 \pm 20$ & $183 \pm 36$ & $1767 \pm 36$ & -16.25 & -29.55 & S. patens & SLIP \\
\hline OS-109784 & 41.55481 & -70.5067 & 52 & -45 & $370 \pm 20$ & $447 \pm 52$ & $1503 \pm 52$ & -11.74 & -52.34 & S. patens & SLIP \\
\hline OS-109780 & 41.55481 & -70.5067 & 58 & -51 & $470 \pm 20$ & $516 \pm 20$ & $1434 \pm 20$ & -13.27 & -63.75 & D. spicata & Limit \\
\hline OS-109961 & 41.5548 & -70.5068 & 68 & -55 & $580 \pm 20$ & $607 \pm 34$ & $1343 \pm 34$ & -12.73 & -76.83 & D. spicata & SLIP \\
\hline OS-109778 & 41.5548 & -70.5068 & 78 & -65 & $660 \pm 25$ & $611 \pm 60$ & $1339 \pm 60$ & -13.44 & -85.8 & D. spicata & Limit \\
\hline OS-109783 & 41.5548 & -70.5068 & 85 & -72 & $620 \pm 20$ & $599 \pm 57$ & $1351 \pm 57$ & -11.74 & -81.35 & S. patens & SLIP \\
\hline OS-109959 & 41.55481 & -70.5068 & 98 & -88 & $905 \pm 20$ & $854 \pm 65$ & $1096 \pm 65$ & -12.75 & -113.4 & D. spicata & SLIP \\
\hline OS-109777 & 41.55481 & -70.5068 & 105 & -95 & $970 \pm 20$ & $861 \pm 70$ & $1089 \pm 70$ & -25.33 & -120.4 & D. spicata & SLIP \\
\hline OS-109956 & 41.55481 & -70.5068 & 109 & -99 & $950 \pm 20$ & $852 \pm 23$ & $1098 \pm 23$ & -23.79 & -118.5 & bulk & Limit \\
\hline OS-109960 & 41.55481 & -70.5069 & 118 & -106 & $1180 \pm 45$ & $1109 \pm 76$ & $841 \pm 76$ & -25.39 & -142.9 & bulk & Limit \\
\hline OS-109774 & 41.55481 & -70.5069 & 125 & -113 & $970 \pm 25$ & $860 \pm 73$ & $1090 \pm 73$ & -11.81 & -120.4 & D. spicata & Limit \\
\hline OS-109958 & 41.55485 & -70.5071 & 31 & -134 & $1260 \pm 30$ & $1218 \pm 63$ & $732 \pm 63$ & -24.04 & -151.9 & bulk & Limit \\
\hline OS-109775 & 41.55483 & -70.507 & 138 & -126 & $1240 \pm 20$ & $1211 \pm 52$ & $739 \pm 52$ & -23.57 & -149.2 & J. gerardii & Limit \\
\hline OS-109779 & 41.55485 & -70.5071 & 148 & -151 & $1500 \pm 20$ & $1380 \pm 33$ & $570 \pm 33$ & -25.16 & -177 & D. spicata & Limit \\
\hline OS-109724 & 41.55483 & -70.507 & 151 & -142 & $1240 \pm 20$ & $1211 \pm 52$ & $739 \pm 52$ & -23.51 & -149.5 & J. gerardii & SLIP \\
\hline
\end{tabular}

foraminifera were counted and identified to species level using a binocular microscope. Total foraminiferal abundances in the base of basal and basal peats varied from 62 to 305 individuals with between one and three species. Only samples with sufficient foraminifera and adjacent radiocarbon samples were used to produce a sea level index point in each basal core. Additionally, we counted foraminifera in surrounding samples to establish that the assemblage was representative of the prevailing environmental conditions at the time the sediment was deposited.

A standard approach to the development of SLIPs was used, which allows for the estimation of the elevation of former sea-level in relative time and space with associated uncertainties (Engelhart and Horton, 2012). Here, we use salt marsh foraminifera as a proxy sea-level indicator because of their well-established relationship with the frequency and duration of tidal exposure, resulting in the elevational zoning of foraminifera assemblages from the upland to the tidal flats (e.g., Edwards et al., 2004; Kemp et al., 2017). The range of tidal elevation over which a particular sea-level indicator forms is called the indicative meaning, which contains a midpoint termed the reference water level and an indicative range which references the upper and lower elevation of the indicator (van de Plassche, 1986; Woodroffe and Barlow, 2015). Relative sea level is then reconstructed by assigning a reference water level and indicative range to each paleo assemblage based on their similarity to modern assemblages. Ecological zonation of foraminifera assemblages is comparable across different climates, marsh flora, and tidal ranges along the Atlantic coast of North America, resulting in low marsh foraminifera assemblages assigned elevations between mean tide level (MTL) and mean high water (MHW) and high marsh assemblages elevations between MHW and highest astronomical tide (HAT) (Kemp et al., 2017).

To determine relative sea-level trends through time, the SLIPs presented here were integrated with decadally averaged tide gauge data from Woods Hole (1932-2015) within an Errors-In-Variables Integrated Gaussian Process (EIV-IGP) model (Cahill et al., 2015). The EIV-IGP model takes into account both the vertical (tidal frame) and temporal (radiocarbon age) uncertainties associated with individual SLIPs and also accounts for their uneven spacing through time (Hawkes et al., 2016). The EIV-IGP model uses a Gaussian process to model the evolution of the rates of sea-level change throughout the observation time period (Williams and Rasmussen, 1996). The sea-level process is derived from the rate process as the integral of the Gaussian process plus measured and estimated vertical uncertainty. Time measurement uncertainties are accounted for through setting the model in an EIV framework (Dey et al., 2000).

\subsection{Vegetation sampling}

The Waquoit Bay National Estuarine Research Reserve conducts yearly vegetation surveys at Sage Lot Pond (NOAA NERRS, 2017). Three transects (130-155 m) across the sediment core collection area were sampled every $\sim 10 \mathrm{~m}$ over an elevation gradient of $90 \mathrm{~cm}$ from the high to low marsh (Fig. 1). Plots ( $1 \mathrm{~m}^{2}$ quadrat) were permanently installed in 2011 and sampled annually in August. Vegetation distribution parameters measured include: percent cover by species to $1 \%$ if less than $15 \%$, otherwise to $5 \%$, with all ground cover summing to $100 \%$, and bare sediment and wrack included in the unvegetated sediment category (overstory vegetation is not included); stem count in a $0.01 \mathrm{~m}^{2}$ subplot; and canopy height (S. alterniflora only), defined as the horizontal plane of $4 / 5$ of the plants (2011-2014) or the three individual plants closest to each of the four quadrat corners (2015-2016).

\subsection{Elevation control and tidal datums}

The marsh surface elevations at the core collection sites and vegetation plots were surveyed with a Trimble Real-Time Kinematic Geographic Positioning System. All data was projected to NAD 1983 Massachusetts State Plane FIPS 2001 and elevations are given relative to NAVD88 with an elevation accuracy of $2-3 \mathrm{~cm}$. In order to determine local tidal datums, an RTK GPS-surveyed sensor collected water levels at Sage Lot Pond from January 2012 through December 2016. The local tidal datum was determined by tying monthly mean datums to the nearby Woods Hole station 8,447,930 using the modified-range ratio method for semidiurnal tides (NOAA, 2003). The resulting datums are corrected to the 1983-2001 National Tidal Datum Epoch, and include MSL, MHW, and the HAT that is predicted over the epoch (Fig. 2). Sage Lot Pond experienced nearly the same MSL $(-0.117 \mathrm{~m}$ NAVD88) as Woods Hole with a smaller mean range of $0.442 \mathrm{~m}$, MHW of $0.094 \mathrm{~m}$, and HAT of $0.463 \mathrm{~m}$. Water level data lapses occurred, especially during winter, so only months with $95 \%$ data collection were used. To test whether this seasonal sampling introduced significant bias, lapses in data collection were applied to Woods Hole station measurements, resulting in higher means by $1.3 \mathrm{~cm}$ on average. This bias is less than the estimated generalized error of these datum calculations $(1.52 \mathrm{~cm})$, thus the latter error is considered an appropriate, conservative estimate.

\section{Results}

\subsection{Modern plant community structure and elevation}

Six years of annual vegetation surveys reveal that across the $0.9 \mathrm{~m}$ 
elevation gradient at the SLP marsh, S. alterniflora dominates at low elevation, $-0.15-0.30 \mathrm{~m}$ relative to MSL in $2013(-0.0337 \mathrm{~m}$ NAVD88), while at higher elevations, D. spicata and $J$. gerardii had a slightly lower elevation preference (0-0.70 m above MSL) than $S$. patens $(0-0.90 \mathrm{~m}$ above MSL, Fig. 3). The elevation distribution of each species was defined by fitting a hyperbola to the maximum vegetation cover observed at each elevation and is used only to demonstrate the preferred elevation of the high and low marsh species relative to MSL (2013 data shown in Fig. 3a). Over this time, within the high marsh elevation zone, there is a slight, but not significant, decrease in percent cover of combined high marsh species from 29 to $23 \%\left(\mathrm{r}^{2}=0.64\right.$, $\mathrm{p}=0.06$, Fig. $3 \mathrm{~b}$ ), while there is no significant trend in either $S$. alterniflora $\left(\mathrm{r}^{2}=0.07, \mathrm{p}=0.61\right)$ or unvegetated sediment $\left(\mathrm{r}^{2}=0.07\right.$, $\mathrm{p}=0.62$ ) cover. Within the high marsh elevation zone, stem density significantly declined for $S$. patens $\left(\mathrm{r}^{2}=0.87, \mathrm{p}<0.05\right.$, Fig. 3c), with a concurrent, but not significant, increase in J. gerardii, $\left(r^{2}=0.29\right.$, $\mathrm{p}=0.27$, Fig. $3 \mathrm{c}$ ), which has a lower elevation preference.

\subsection{Bulk sediment core properties}

A series of one-way ANOVA tests were conducted to evaluate differences (dry bulk density (DBD), weight \% C, and C density) between the 11 cores from 4 marsh sites (cores identified A, B or C; Figs. 1 and 4). Mean core DBD ranged from 0.13 to $0.17 \mathrm{~g} / \mathrm{cm}^{3}$; core $\mathrm{HBC}$ was the only one significantly lower than the other cores ( $p<0.05$; Table S2). The Hamblin Pond cores (HBA, HBB, and HBC) had higher weight \% C (mean range 27.4-33.9\%) than all other cores (16.0-25.9\%) except EPA (28.1\%) (Table S3). Mean C density, the product of DBD and weight $\% \mathrm{C}$, ranged from 31.8 to $44.6 \mathrm{~kg} / \mathrm{m}^{3}$, with GPB having significantly lower carbon density than Hamblin Pond cores and EPB (Table S4).

Down-core trends were evaluated with linear regression analysis. Only four cores had significant $(p<0.05)$ down core trends in dry bulk density: SLPA increases $\left(0.14-0.21 \mathrm{~g} / \mathrm{cm}^{3}\right)$, while in SLPC $\left(0.16-0.13 \mathrm{~g} / \mathrm{cm}^{3}\right)$, GPA $\left(0.20-0.11 \mathrm{~g} / \mathrm{cm}^{3}\right)$, and HBA $(0.20-0.12 \mathrm{~g} /$ $\mathrm{cm}^{3}$ ) decreases with depth. Notably, all but four cores have significant increases in weight \% C down core (Table S5). However, while the trend in the high marsh transition core (SLPB) was not significant ( $p=0.051$ ), weight $\% \mathrm{C}$ decreased steeply with depth from $30 \%$ to $7 \%$ at the base of the peat $(11 \mathrm{~cm})$. There were only three cores with significant down-core trends in carbon density, the product of DBD and weight \% C: SLPA $\left(33.2-66.5 \mathrm{~kg} / \mathrm{m}^{3}\right)$ and HBC $\left(36.5-46.8 \mathrm{~kg} / \mathrm{m}^{3}\right)$ increase with depth, while EPB $\left(47.6-35.8 \mathrm{~kg} / \mathrm{m}^{3}\right.$ ) decreases (Table S5).

\subsection{Sediment accretion over the past century}

The age and accretion rate for each $1 \mathrm{~cm}$ section was determined with the continuous rate of supply model from unsupported ${ }^{210} \mathrm{~Pb}$ sediment activities and sediment density (Fig. 4) (Appleby and Oldfield, 1978). The past century of deposition reaches from the surface to a depth of $24-29 \mathrm{~cm}$ in the low marsh and to $11 \mathrm{~cm}$ at the high marsh transition site (SLPB). Accretion rates are highly variable $(n=310$ in 11 cores), with a range of $0.8-9.7 \mathrm{~mm} / \mathrm{yr}$. The ten cores from the area that is now low marsh at all four sites are not statistically different from each other, based on one-way ANOVA tests, so all ten cores have been merged to create a unified record of accretion over the past century (Fig. 4). At these four marsh sites, there is a steady rise in accretion rates since 1900. For example, in the decade from 2005 to 2015, mean accretion rates across all low marsh sites were $4.2 \pm 1.5 \mathrm{~mm} / \mathrm{yr}$, compared to $2.3 \pm 1.0 \mathrm{~mm} / \mathrm{yr}$ in the decade from 1900 to 1910 , with uncertainty $( \pm$ ) expressed as the standard deviation of all measurements for each treatment. However, accretion rates in the Sage Lot Pond high marsh transition zone core (SLPB) were statistically disparate from low marsh rates. At this site, there were much lower accretion rates over the same two decades, $0.8 \mathrm{~mm} / \mathrm{yr}$ in the first decade of the 20th century, compared to $2.1 \mathrm{~mm} / \mathrm{yr}$ in the most recent decade
(Fig. 4). Notably, over the past century, average accretion in the high marsh increased by $1.3 \mathrm{~mm} / \mathrm{yr}$, compared to a $1.9 \pm 1.8 \mathrm{~mm} / \mathrm{yr}$ increase in the low marsh. This soil core data is available in an accompanying data release through the U.S. Geological Survey ScienceBase (Gonneea et al., 2018).

\subsection{Relative sea-level reconstruction and paleomarsh accretion rates}

To develop a RSL curve to assess marsh response and compare paleo to modern rates of change, a total of nine sea level index points and eight terrestrial limit points spanning the last $\sim 1500$ years were developed from measured ${ }^{14} \mathrm{C}$ dates of basal peat, foraminiferal assemblages, and associated sample elevations (110 y before present $(-18 \mathrm{~cm}$ NAVD88) to 1380 y before present ( $-151 \mathrm{~cm}$ NAVD88) (Table 1$)$ ). The SLIPs included seven base of basal peat $(<5 \mathrm{~cm}$ above the sand contact) and two basal peat ( $>5 \mathrm{~cm}$ above the sand contact) samples distributed over an elevation range of $1.24 \mathrm{~m}$ (Fig. 5). All foraminiferal assemblages (Haplophragmoides sp., Jadammina macrescens, and Trochammina inflata) represent a high marsh ecological zone (MHW to HAT), with an indicative range of $\pm 0.18 \mathrm{~m}$ based on the tidal datum and modern assemblages, resulting in a total elevation uncertainty of $\pm 0.24 \mathrm{~m}$ (Figs. $2 \&$ 5A, Table 1) (Edwards et al., 2004; Kemp et al., 2015). In 8 cases, the basal peat samples were absent of foraminifera, with 4 containing thecamoebians, a fresh water testate amoeba (Kemp et al., 2017), so these serve as terrestrial limiting points that indicate an environment above the tidal frame ( $>$ HAT).

The 9 SLIPs, 8 terrestrial limiting points, and decadally-averaged Woods Hole tide gauge data (1932-2015) were integrated within an EIV-IGP model (Cahill et al., 2015) to produce a record of RSL spanning the period between 557 and $2015 \mathrm{CE}$ (Fig. 5B). There was a $1.5 \pm 0.4 \mathrm{~m}$ rise in RSL during this period (Fig. $5 \mathrm{C}$ ). The mean rate of relative sea-level rise for the 1200-years prior to 1850 was $0.9 \pm 0.2 \mathrm{~mm} / \mathrm{yr}$, with the rates dipping to $\sim 0.6 \mathrm{~mm} / \mathrm{yr}$ from 1400 to 1600. Between 1850 and 2015, sea level rose at a rate of $2.3 \mathrm{~mm} / \mathrm{yr}$, with maximum rates $(3.2 \mathrm{~mm} / \mathrm{yr})$ occurring in the past decade.

\subsection{Carbon storage rates}

Carbon storage rate refers to the amount of carbon stored per year in salt marsh sediment of various ages. Carbon storage was calculated from carbon density and vertical accretion rates and was evaluated every $2 \mathrm{~cm}$ over the past century based on ${ }^{210} \mathrm{~Pb}$ chronology (Table S7). Carbon storage was determined at lower resolution (two to $10 \mathrm{~cm}$ ) to $557 \mathrm{CE}$ with accretion rates and ages from the EIV-IGP model, assuming that marsh accretion was equivalent to relative sea-level rise. Carbon storage rates from 557 to $1800 \mathrm{CE}$ were $39 \pm 14 \mathrm{~g} \mathrm{C} / \mathrm{m}^{2} / \mathrm{yr}$, with an increase to $63 \pm 18 \mathrm{~g} \mathrm{C} / \mathrm{m}^{2} / \mathrm{yr}$ in the century from 1800 to 1900 (Fig. 4). Carbon storage has continued to accelerate, with rates in locations that are now low marsh reaching $76 \pm 33 \mathrm{~g} \mathrm{C} / \mathrm{m}^{2} / \mathrm{yr}$ from 1900 to 1910 and $129 \pm 50 \mathrm{~g} \mathrm{C} / \mathrm{m}^{2} / \mathrm{yr}$ from 2005 to 2015 . At the same time, there has been little change in carbon storage rates at locations that are presently the high marsh transition zone (SLPB, 1900-1910: $85 \pm 36 \mathrm{~g} \mathrm{C} / \mathrm{m}^{2} / \mathrm{yr} ; 2005-2015: 66 \pm 11 \mathrm{~g} \mathrm{C} / \mathrm{m}^{2} / \mathrm{yr}$ ). There is a minimum in carbon storage in the high marsh transition zone during the 1930-40's associated with low carbon content in the sediments. However, a multiple linear regression analysis of soil carbon density, accretion rate, and carbon storage rates indicates that vertical accretion rates exert $\sim 6.5$ times greater control on carbon storage rates than does sediment carbon density (Type III Sum of Squares effect size, AR $=186$, $\mathrm{C}$ density $=33$ ). Thus, accretion rates exert the dominant control on carbon storage rates in these salt marshes. 


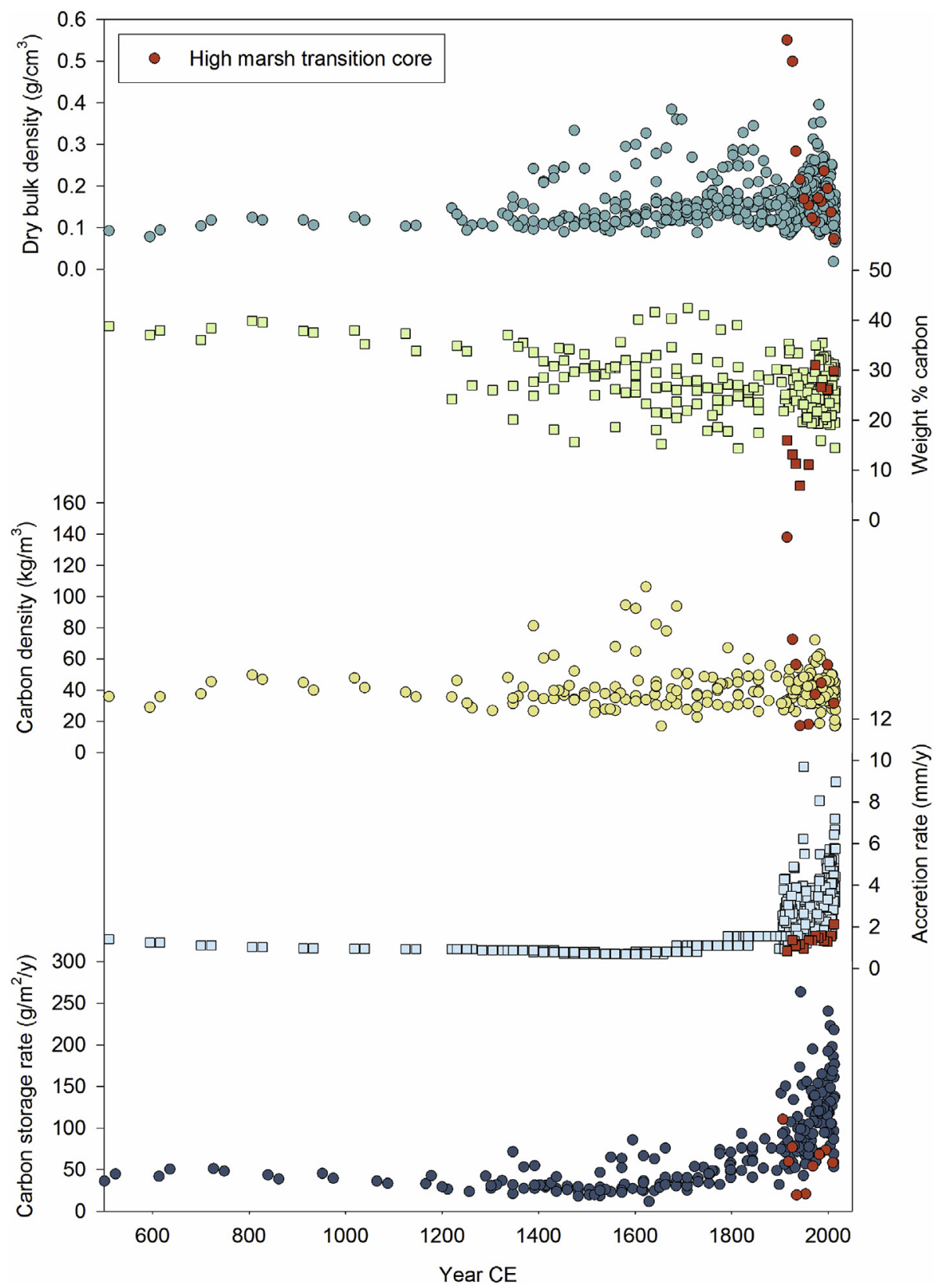

Fig. 4. Dry bulk density, weight \% C, C density, accretion rate, and carbon storage through time. In all plots, red symbols are the high marsh transition zone core (SLPB). Accretion rates prior to 1900 are based on EIV-IGP modeling of SLIP ${ }^{14} \mathrm{C}$ dates and elevations. (For interpretation of the references to colour in this figure legend, the reader is referred to the Web version of this article.)

\section{Discussion}

\subsection{Relative sea-level history}

For the majority of the nearly 1500 -year record, relative sea-level rise was relatively stable at $0.9 \pm 0.2 \mathrm{~mm} / \mathrm{yr}$ (Fig. 5). This late Holocene stability has been documented in numerous other sea-level reconstructions (e.g., Donnelly, 2006; Kemp et al., 2017). The accretion of the paleo high marsh surface is inferred to mirror this rate and was slowly transgressing landward and upward throughout the late Holocene (Fig. 6). The collapse of the Laurentide Ice Sheet proglacial forebulge after the last glacial maximum led to coastal subsidence from Maine to Florida, with the ongoing glacial isostatic adjustment (GIA) rate varying spatially with distance from the former center of the ice sheet (Barnhardt et al., 1995; Engelhart et al., 2009; Hawkes et al., 2016). According to the predictions from the ICE-6G model (version
VM5a), the current rate of coastal subsidence at our study site is $1.2 \mathrm{~mm} / \mathrm{yr}$ and has been relatively constant over the past 5000 years (Peltier et al., 2015). Thus, prior to 1850, the primary driver of relative sea-level rise along the U.S. Atlantic coast was land-level changes associated with spatially-variable GIA, as differences between these two rates $(0.9 \pm 0.2 \mathrm{~mm} / \mathrm{yr}$ and $1.2 \mathrm{~mm} / \mathrm{yr})$ are within the uncertainties of both models (Engelhart et al., 2011; Peltier et al., 2015). The recent acceleration in relative sea-level rise since 1850 can be attributed to the thermal expansion of ocean water, melting of land ice, and changes to ocean circulation patterns (Rietbroek et al., 2016; Yin et al., 2009). From 1850 to 2015 , sea-level rose $2.3 \mathrm{~mm} / \mathrm{yr}$ with a maximum rate $(3.2 \mathrm{~mm} / \mathrm{yr})$ occurring in the last decade. These rates represent nearly a threefold increase over the previous 1500 years and provide the catalyst for ecological shifts in salt marsh structure over the past century. 


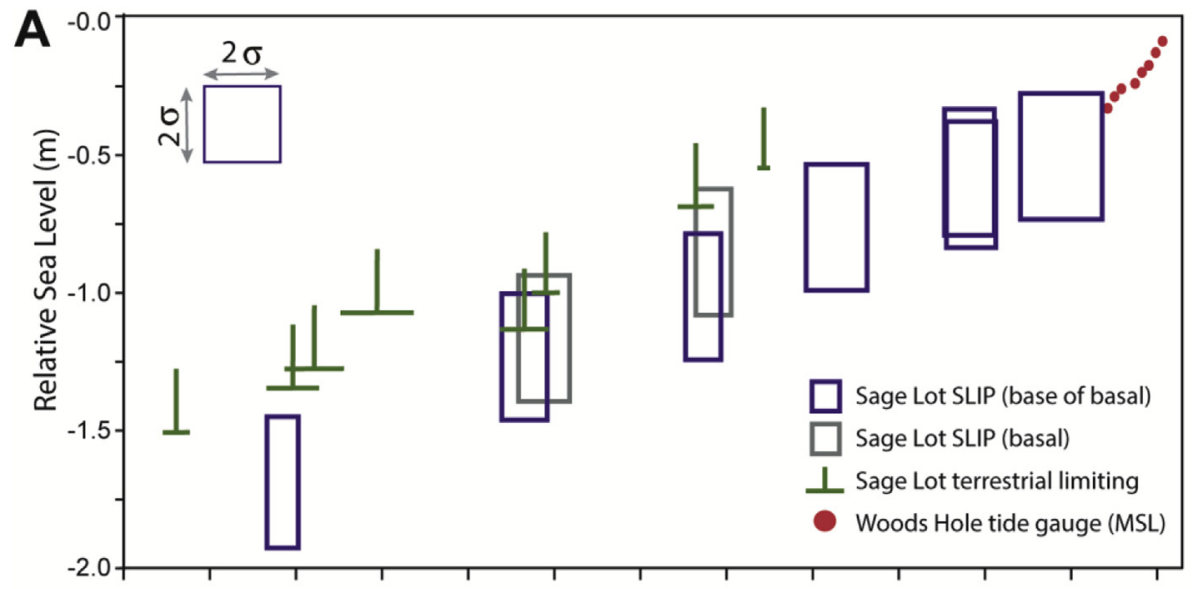

Fig. 5. Relative sea-level reconstruction for Sage Lot Pond marsh. A) 9 Sage Lot SLIPs and 8 Sage Lot limiting points shown with 2 sigma vertical and temporal uncertainty window (rectangles). Key to data type in lower right. B) Modeled relative sea level record (yellow) relative to NAVD88 shown with $68 \%$ (light blue) and 95\% (dark blue) confidence intervals. Midpoints of SLIPs and limiting data shown with tan circles. Data key is shown at bottom. C) Median probability rate of relative sea-level rise (yellow line) shown with 68\% (light gray) and 95\% (dark gray) confidence intervals. Red dashed line shows rate of rise recorded at Woods Hole tide gauge since 1932. Gray dashed line marks the background GIA. (For interpretation of the references to colour in this figure legend, the reader is referred to the Web version of this article.)
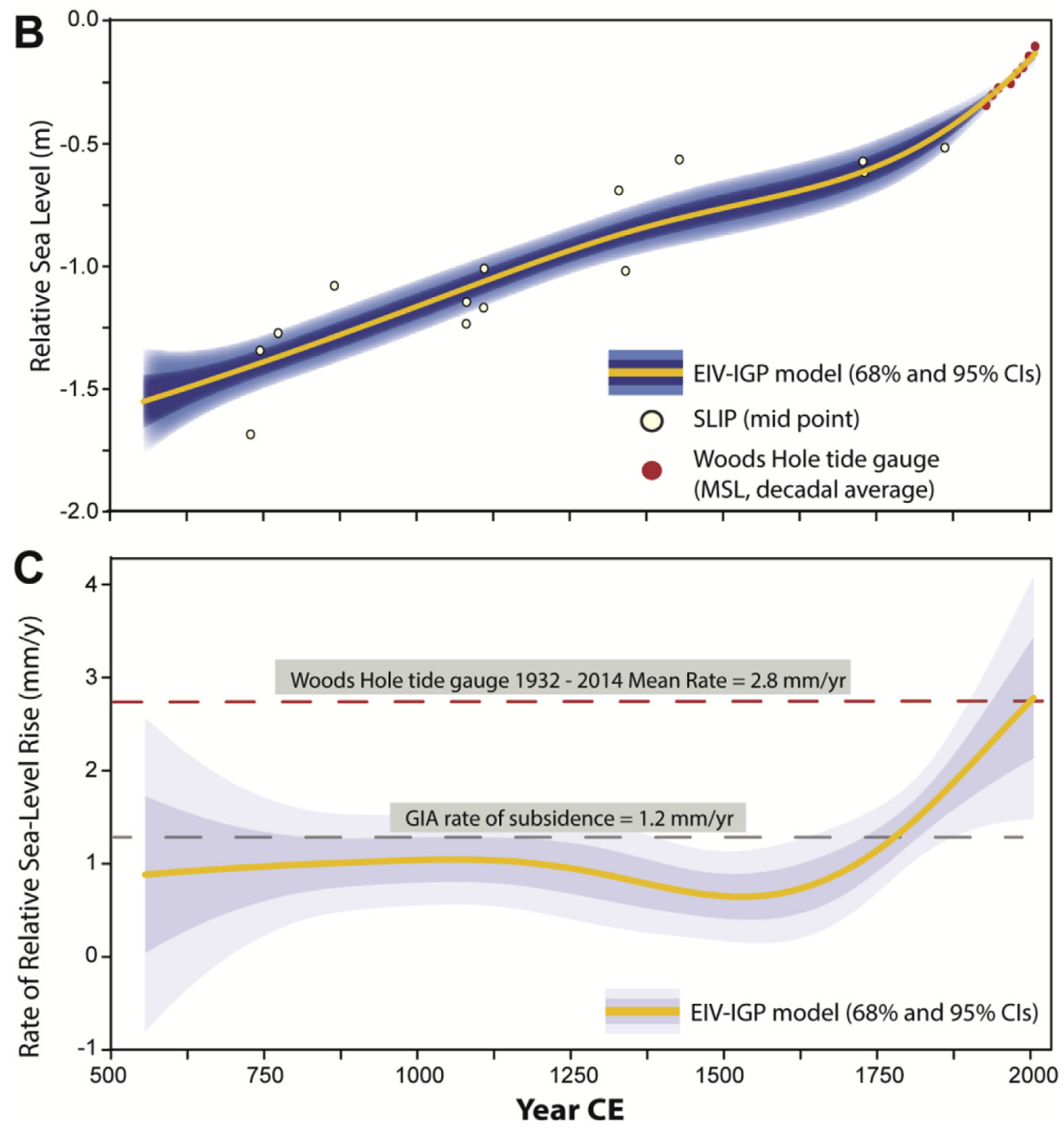

\subsection{Marsh transgression}

Vegetation surveys conducted yearly from 2011 to 2016 at Sage Lot Pond offer some direct evidence of low marsh species transgression into former high marsh regions. A dramatic decrease in $S$. patens stem density in the high marsh zone $(2825 \pm 2720$ to $720 \pm 755$ stems/ $\mathrm{m}^{2}, \mathrm{r}^{2}=0.87, \mathrm{p}<0.05$, Fig. 3) occurred over six years, coincident with a non-significant decrease in total high marsh species coverage $\left(29-23 \%, r^{2}=0.64, p=0.06\right)$. While there was no concurrent increase in low marsh species coverage in the high marsh, such an increase has been observed over the past several decades in similar fringing marshes in Rhode Island (Donnelly and Bertness, 2001; Raposa et al., 2017) and Massachusetts (Smith, 2015). We interpret this decrease in S. patens stem density to be driven by increased inundation beyond this species' preferred flooding and salt tolerance regime.

Prior to 1850 the rate of high marsh vertical accretion closely mirrored the rate of relative sea-level rise, supporting lateral marsh expansion into adjacent coastal forests. Since 1932 (Woods Hole tide gauge established), the high marsh transition zone has lost $11.4 \mathrm{~cm}$ of elevation capital relative to sea level. Elevation capital loss rates of $1.4 \mathrm{~mm} / \mathrm{yr}$ indicate that the high marsh cannot maintain lateral transgression at a sufficient pace to maintain the paleo marsh habitat structure. In addition, this is likely an underestimate of total elevation capital lost since the onset of acceleration in relative sea-level rise, as this study, and others, document the acceleration beginning as early as 1860 (Kemp et al., 2017). However, we confine this analysis to the 


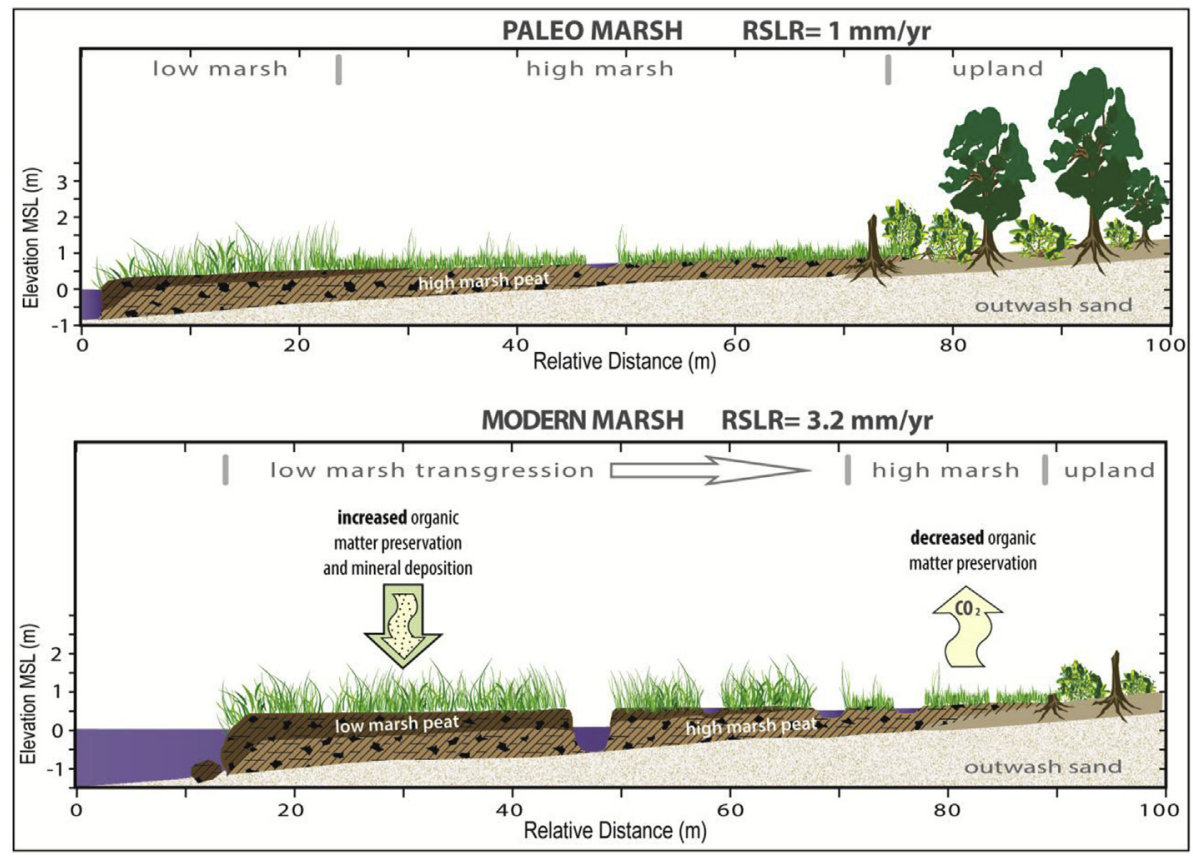

Fig. 6. Conceptual model of paleo and modern marsh profiles. The marsh platform is built on Pleistocene outwash sands, initially overlaid by high marsh peat, followed by a slow rate of transition to low marsh. During the late Holocene relative sea level rose at a rate of approximately $1.1 \mathrm{~mm} / \mathrm{yr}$, resulting in a relatively stable marsh surface dominated by high marsh plant communities. In the modern marsh, a current rate of relative sea-level rise of $3.2 \mathrm{~mm} / \mathrm{yr}$ results in transgression of low marsh vegetation over the past high marsh. The high marsh is unable to keep up with the current rate of eustatic sea-level rise and has lost elevation within the tidal frame, leading to a loss in its spatial extent concurrent with replacement by low marsh. Factors leading to the resilience of the low marsh include increased biomass production and preservation in conjunction with increased mineral deposition. period of instrumented sea level records. From this, we predict that the total area of high marsh habitat is declining while low marsh habitat transgresses landward, restructuring the ecological zones across the marsh platform.

The accretion response of the low marsh has been more dynamic. A segmented regression analysis of relative marsh elevation indicates that from 1932 to 1974, the area that is now low marsh also lost elevation at rates between 0.03 and $0.6 \mathrm{~mm} / \mathrm{yr}$, for a total elevation capital loss of $0.2-4.1 \mathrm{~cm}$ in 42 years. After 1974 , the marsh transitioned to elevation stability and recovery relative to mean sea-level (Fig. 7). This period of elevation stability occurs when the marsh platform reaches the relative elevation where vegetation surveys indicate $S$. alterniflora dominates marsh vegetation (for this site $\sim 17 \mathrm{~cm}$ above MSL, Figs. 3 and 7). For the subsequent 41 years, the marsh platform elevation relative to MSL stabilized, and in 7 of the 10 low marsh cores, regained elevation capital at relative rates of $0.06-1.3 \mathrm{~mm} / \mathrm{yr}$, with accretion rates of $3.4 \pm 0.7 \mathrm{~mm} / \mathrm{yr}$ on average, matching, and potentially slightly outpacing, the Woods Hole instrumental relative sea-level rise rate of $3.2 \mathrm{~mm} / \mathrm{yr}$. Three low marsh cores (GPA, HPA, EPB) continued to lose elevation capital at rates of $0.2-0.4 \mathrm{~mm} / \mathrm{yr}$. One potential reason these cores continued to lose elevation is that they are lower in the tidal frame, so that increased inundation results in reduced, rather than enhanced, biomass productivity, and thus are responding negatively to sea-level rise (Table S1). These portions of the marsh would potentially be identified as areas to monitor for future elevation loss.

Notably, there were no significant trends in accretion response

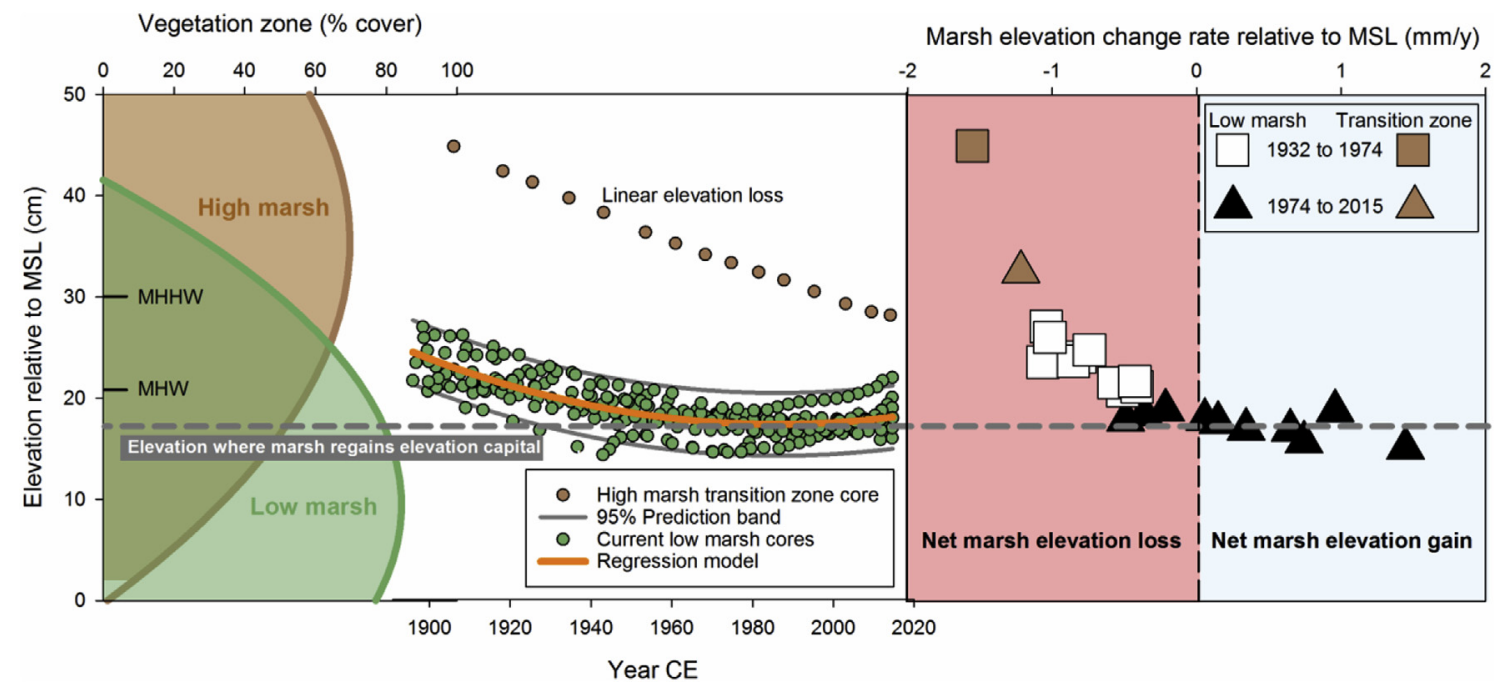

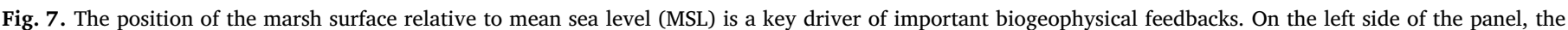

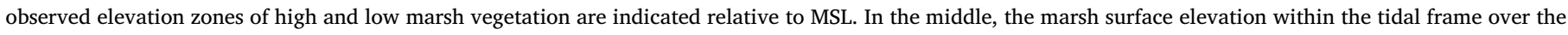

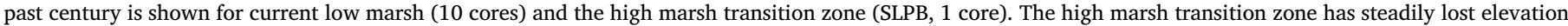

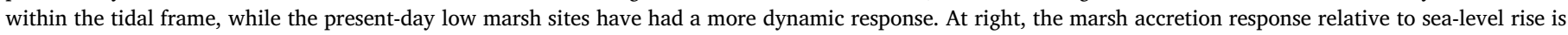

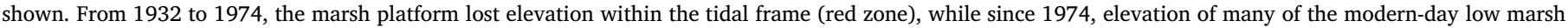

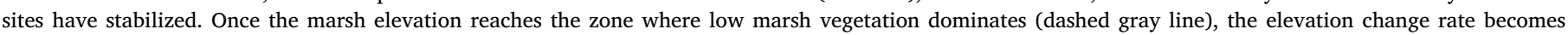

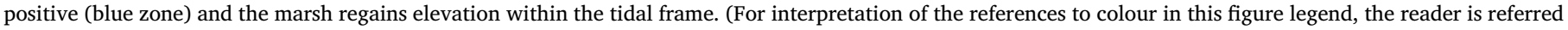
to the Web version of this article.) 
between the four marshes, despite their twenty-fold difference in nitrogen loading rates. Thus, nitrogen loading does not appear to be a primary control on accretion rates or carbon storage in these systems, unlike field experiments that indicate a positive accretion response to nitrogen fertilization (Davis et al., 2017; Fox et al., 2012). This may be potentially due to the manner of nitrogen loading, which in these estuaries occurs mainly through atmospheric deposition and groundwater inputs to the estuary, with nitrogen likely taken up within the estuary and transformed to particulate or dissolved organic nitrogen forms prior to entering the salt marsh system through tidal exchange (Valiela et al., 2016). This is in contrast to experimental nitrogen-loading treatments that directly add inorganic nitrogen to salt marsh systems, or add nitrogen at higher rates.

Low marsh vegetation succession resulted in enhanced elevation building capacity for the marsh platform. We explore three potential mechanisms for the observed elevation recovery following vegetation succession, including 1) enhanced biomass production as low marsh species dominate the platform, 2) differential rates of organic matter preservation at the two elevation zones and at different peat depths and ages, and 3) enhanced mineral deposition. All three processes could result in elevation gains within salt marshes, which derive their volume from both organic and mineral matter.

\subsubsection{Role of biomass production on elevation resilience}

The uptick in accretion rates begins around 1974 as the marsh platform reaches the elevation within the tidal frame where $S$. alterniflora dominates over high marsh species (Fig. 7). Biomass production in the $S$. alterniflora-dominated low marsh was $105 \%$ greater than the high marsh (above ground: (low) $657 \pm 133 \mathrm{~g} \mathrm{C} / \mathrm{m}^{2}$, (high) $516 \pm 82 \mathrm{~g} \mathrm{C}$ / $\mathrm{m}^{2}$; below ground: (low) $5750 \mathrm{~g} \mathrm{C} / \mathrm{m}^{2}$, (high) $2605 \mathrm{~g} \mathrm{C} / \mathrm{m}^{2}$ (MosemanValtierra et al., 2016)). If peat organic matter storage is sourced solely from below ground biomass (Nyman et al., 2006), then the low marsh region has a much greater capacity to not only bury carbon, but to gain elevation through organic matter storage, since, in peat marshes, organic material is the main contributor to elevation (Morris et al., 2016; Nyman et al., 2006). Assuming the preservation rate, or the fraction of annual biomass production that is preserved in peat, is constant across marsh zones, then it is possible to estimate the maximum elevation growth rate based on biomass production (Morris et al., 2016). Holding preservation at $10 \%$, based on plant lignin concentration (Benner et al., 1991; Hodson et al., 1984), and using an organic matter density of $0.085 \mathrm{~g} / \mathrm{cm}^{3}$ (Morris et al., 2016), maximum vertical accretion is $6.8 \mathrm{~mm} / \mathrm{yr}$ in the low marsh and $3.1 \mathrm{~mm} / \mathrm{yr}$ in the high marsh (i.e. $0.575 \mathrm{~g} / \mathrm{cm}^{2} / \mathrm{yr}$ x $0.1 \mathrm{~g}$ lignin $/ \mathrm{g}$ dry weight $/ 0.085 \mathrm{~g} / \mathrm{cm}^{3}$ ). These theoretical values are higher than observed accretion rates based on the ${ }^{210} \mathrm{~Pb}$ chronology $(4.2 \pm 1.5$ and $2.3 \pm 1.0 \mathrm{~mm} / \mathrm{yr}$ for the low and high marsh regions, respectively, from 2005 to 2015). Thus, enhanced biomass production in the low marsh could potentially account for the elevation gains observed during low marsh transgression as $S$. alterniflora dominates marsh vegetation.

\subsubsection{Role of soil organic matter preservation on elevation resilience}

Since organic matter is the primary contributor to vertical accretion in marshes with high weight \% C (Neubauer, 2008; Turner et al., 2002), such as those in this study (16-42 wt \% C), ongoing decomposition in aging peat may create apparent accretion rates that are higher near the surface than at depth. As organic matter is broken down and remineralized by microorganisms, carbon is lost along with the associated volume of organic matter (Neubauer, 2008). Thus, sediment profiles with constant organic matter inputs and ongoing decomposition should exhibit a decrease in weight \% C and increase in sediment density, and over time, a decrease in relative marsh surface elevation. In a reconstruction of the marsh surface through time, those processes would appear as an increase in accretion rate in recent deposits, as observed here. We first evaluate the change in weight $\% \mathrm{C}$ and DBD with depth to determine if preservation differs between elevation zones and flooding regimes and through time. Seven of the ten low marsh cores have significant increases in weight $\% \mathrm{C}$ with depth. If conditions when the peat was formed in the past are comparable to those now, this finding suggests that organic matter at depth is not undergoing continual remineralization and loss in these cores. DBD, which we expect to increase over time with autocompaction and remineralization (Cahoon et al., 1995; Day et al., 2011), only increases significantly in one core (SLPA), while in three cores, DBD significantly decreases (SLPC, GPA, HBA) (Table S5). Conversely, weight $\% \mathrm{C}$ in the high marsh transition core (SLPB) drops from 30 at the surface to $7 \%$ at depth, with only a slight increase in density $\left(0.14-0.17 \mathrm{~g} / \mathrm{cm}^{3}\right)$; neither trend is significant, however, likely due in part to the limited number of samples over the $14-\mathrm{cm}$ peat transition profile ( $\mathrm{n}=6$ for weight $\% \mathrm{C}, \mathrm{n}=10$ for DBD).

If productivity over the entire history of the high marsh transition zone core was similar to the present day, then ongoing decomposition within the short, infrequently flooded peat profile may be responsible for the recent trend of greater accretion rates in the high marsh. Using a two-end member sediment mixing model (Morris et al., 2016), it is possible to predict soil volume losses from changes in DBD and organic matter content, with the following assumptions: 1) each fraction has a fixed density (organic matter: $0.085 \mathrm{~g} / \mathrm{cm}^{3}$ and mineral matter: $1.99 \mathrm{~g}$ / $\mathrm{cm}^{3}$ ), 2) only organic matter is lost during decomposition, and 3) changes in organic matter content are due only to decomposition, not variable organic matter input and storage rates. The last assumption is unlikely to be met given the dynamic environmental conditions that have occurred over the past century in salt marshes; however, it offers a conservative approach to evaluating whether these soil records reflect real changes in accretion and carbon storage versus the signature of decomposition, since we assume all reduction in organic matter results in lost soil volume, rather than changes in organic matter reflecting environmental and depositional differences through time.

In the high marsh transition zone core (SLPB) down-core DBD increases by $21 \%\left(0.14-0.17 \mathrm{~g} / \mathrm{cm}^{3}\right)$, while weight $\% \mathrm{C}$ decreases by $77 \%$ (30-7\%). Based on these measurements, the soil volume associated with organic matter is $65 \%$ greater at the top of the core compared to the bottom. Likewise, accretion rates are $62 \%$ greater at the surface compared to rates at depth $(2.1-0.8 \mathrm{~mm} / \mathrm{yr})$. Thus, the entire observed accretion rate difference can be accounted for via loss of organic matter volume at depth. Moreover, it is possible that the accretion rate increase is a transient feature within the sediment column and may not yield sustained elevation gains. The environmental conditions in the high marsh transition zone, including less frequent flooding and greater oxygen exposure, result in continual degradation and compaction of organic matter in shallow peat.

For the low marsh, however, the observed accretion rate increase is interpreted as a persistent feature driven by acceleration in the rate of relative sea-level rise, as discussed below. In low marsh profiles, most of the significant down-core trends are opposite those observed in the high marsh, with higher weight \% C and lower DBD at depth. However, in the soil mixing model described by Morris et al. (2016), large changes in organic content occur over a narrow DBD range $\left(0.1-0.2 \mathrm{~g} / \mathrm{cm}^{3}\right)$, that may be difficult to resolve reliably. Thus there can be a relatively large soil volume loss associated with organic matter remineralization, while dry bulk density is nearly unchanged (Morris et al., 2016). We evaluate the sensitivity of the modeled soil volume loss compared to the observed low marsh variability (interquartile range, $25-75 \%$ of all measurements) in DBD $\left(0.03 \mathrm{~g} / \mathrm{cm}^{3}\right)$ and weight $\% \mathrm{C}(3 \%)$. The soil mixing model predicts that a density change of $0.03 \mathrm{~g} / \mathrm{cm}^{3}$ can result in soil volume variability of $25-50 \%$ for soils with a weight $\% \mathrm{C}$ of $25-35 \%$, while change of $3 \mathrm{wt} \% \mathrm{C}$ would be associated with a $10-15 \%$ range in soil volume. The precision of the carbon analysis is much better than the DBD measurement, and likely provides a more accurate assessment of the maximum potential changes in organic matter content, if the entire interquartile range of observations (i.e. DBD: $0.03 \mathrm{~g} / \mathrm{cm}^{3}$ and weight $\%$ C: $3 \%$ ) has occurred in a non-detected down-core trend. A $10-15 \%$ reduction in soil volume would only account for an apparent 
increase in accretion rates of $0.4-0.6 \mathrm{~mm} / \mathrm{yr}$, so at most $18 \%$ of the accretion rate change could be due to organic matter losses that available methods cannot resolve. We conclude then that ongoing organic matter loss does not account for the doubling of accretion rates in recent deposits. This observation that organic matter decomposition not is driving down-core changes in \%C in these low marsh cores may seem counter to the previously mentioned $10 \%$ preservation of biomass production used to predict marsh carbon storage (Morris et al., 2016). It may be that the expansion of an environment conducive to organic matter preservation as salt marshes grow vertically in response to sealevel rise effectively increases the net percent of production that preserved in the subsurface.

\subsubsection{Role of mineral deposition on elevation resilience}

As the marsh platform lowers relative to sea level, increased flooding frequency may increase sediment deposition, as sediment settles onto the marsh surface when it is inundated (Kirwan and Guntenspergen, 2012; Redfield, 1972). Above ground salt marsh plant structures trap sediment, thus there is likely a synergy between organic production and largely mineral sediment deposition in marshes (Kolker et al., 2009). DBD can inform mineral sediment content and inorganic contributions to soil volume. In the low marsh, seven cores had no significant trend in sediment density, three cores do have DBD increases at the top, and one core decreases at the top (Table S5). There is a weak, but significant $\left(r^{2}=0.01, p=0.01\right)$ decrease in accretion rates with increase in density. Indeed, the highest accretion rates occur at the lowest sediment densities (Fig. S2). There is a weak, but significant relationship between vertical accretion rates and both mineral and organic carbon mass accumulation rates (Fig. S2), however the slope is approximately twice as steep for organic carbon as for mineral accumulation. Organic matter accumulation likely contributes more to vertical accretion than does mineral accumulation. Thus, there is evidence that as organic production increases in response to higher inundation levels and shifting plant assemblages, sediment trapping by plants likewise increases, but contribution to sediment volume is modest.

The fate of salt marshes is closely linked to elevation resilience and will likely be challenged by a continued acceleration in relative sealevel rise. This study demonstrates that the marsh platform has been able to build elevation after transitioning to low marsh habitat through positive feedback between increased inundation and enhanced productivity. While multiple models have parameterized possible relative sea-level rise thresholds for marsh drowning based on relatively simple metrics, including inorganic sediment supply, tidal range, and biomass productivity, it is likely potentially dynamic responses to sea-level rise, including evolving ecosystem structure, are not captured in such scenarios (Kirwan and Megonigal, 2013; Morris et al., 2002). Indeed, if we assume current marsh productivity rates and constant preservation rates persist through the future, the maximum accretion rate possible is $6.8 \mathrm{~mm} / \mathrm{yr}$. This would indicate that critical ecosystem services, including carbon storage, storm surge protection, habitat provision, and retention of terrestrial pollutants, may be lost under predicted rates $(8-16 \mathrm{~mm} / \mathrm{yr}$ (IPCC, 2014)) of sea-level rise by 2100 . However, such a threshold is not responsive to future ecological dynamics. In addition, if salt marsh vertical accretion rates are resilient to relative sea-level rise, as shown here and reflected in salt marshes globally (Kirwan et al., 2016a), then salt marsh fate may be more closely linked to migration space (Kirwan et al., 2016b) and processes that reduce marsh area, such as erosion and ponding (Ganju et al., 2017; Mariotti, 2016), indicating that marsh relative sea-level rise thresholds must link vertical and lateral processes.

\subsection{Carbon storage under rising sea level}

Higher accretion rates in recent decades have occurred as vegetation structure has fundamentally changed in salt marshes. Based on the above discussion, we conclude that this increase in vertical accretion rates, which enhances the elevation building capacity of salt marshes, is predominantly driven by increased biomass production of the low marsh grass, $S$. alterniflora, compared to high marsh species, D. spicata, $J$. gerardii, and S. patens, and facilitated by an environment favorable to preservation, including here an expanding accommodation space as sea level rises (Fig. 6). Given the minimal change in carbon density with depth at these sites and across marshes nationally (Holmquist et al., 2018b), changes in carbon storage are primarily driven by dynamic vertical accretion rates. This amplification of carbon storage in modern sediments compared to earlier deposits had previously been hypothesized to be due to ongoing organic matter degradation in older, deeper peat deposits (Neubauer, 2008), but the evidence here indicates that accelerating modern accretion rates are a persistent feature in salt marshes. The carbon storage capacity of low marsh environments, and ultimately their survival under a regime of accelerating relative sealevel rise, depends directly on the total biomass production and amount preserved in the subsurface. If the present-day productivity of low marsh S. alterniflora is already at maximal values and preservation rates are stable (here we assume the marsh can store a maximum of $10 \%$ of productivity within the subsurface, a relatively unconstrained value), then the peak carbon storage rate in the low marsh at these sites is $575 \mathrm{~g} \mathrm{C} / \mathrm{m}^{2} / \mathrm{yr}$. This value is double that proposed by Morris et al. (2016), based on lower below ground biomass production. However, below ground biomass production is variable across sites and species and is likely a function of environmental conditions including flooding regime and salinity (Alldred et al., 2017; Tripathee and Schäfer, 2015). Thus these estimates of maximal C storage may change as further research is done considering the factors controlling production and preservation of below ground biomass.

In the high marsh transition zone, there is evidence that the apparent increase in both accretion rates and carbon storage in recent years is potentially an artifact of ongoing organic matter degradation in the older portions of the soil profile. The high marsh transition zone peat demonstrated a rapid drop in weight \% C with depth consistent with higher organic matter turnover in this infrequently flooded region. We posit that long-term carbon storage rates of $46 \pm 28 \mathrm{~g} \mathrm{C} / \mathrm{m}^{2} / \mathrm{yr}$, as seen prior to 1800 , were at steady state with relative sea-level rise of $\sim 1 \mathrm{~mm} / \mathrm{yr}$, and marsh platforms were likely dominated by high marsh species adapted to infrequent flooding. As relative sea-level rise accelerated, salt marshes transitioned to low marsh dominated vegetation, allowing rapid vertical expansion into an enhanced accommodation space, supporting a new, greater carbon storage rate, here observed to be $129 \pm 50 \mathrm{~g} \mathrm{C} / \mathrm{m}^{2} / \mathrm{yr}$, in line with rates reported globally (Chmura et al., 2003). Enhanced carbon storage in salt marshes responding to rapid relative sea-level rise provides a negative feedback on global climate warming driven by increasing atmospheric greenhouse gas concentration, albeit a modest one, by removing atmospheric $\mathrm{CO}_{2}$ at an enhanced rate and storing it for extended time periods in salt marsh peat. However, the potential doubling or tripling of salt marsh carbon storage under accelerating sea-level rise is likely currently offset by loss and degradation of this vulnerable habitat (Gedan et al., 2009), lessening the impact of global salt marsh response to sea-level rise on atmospheric $\mathrm{CO}_{2}$ levels.

\section{Data and materials availability}

All core data supporting this work is available at www.ScienceBase. gov, https://doi.org/10.5066/F7H41QPP.

\section{Acknowledgements, SAMPLES and DATA}

The authors would like to thank Priya Ganguli, Kara Vadman and Jennifer O'Keefe Suttles for assistance with sample collection and analysis. The authors express gratitude to Waquoit Bay National Estuarine Research Reserve, Chris Weidman, South Cape Beach State 
Park, and the towns of Falmouth and Mashpee for access to field sites and collaboration at the Salt Marsh Observatory. We also thank W.R. Peltier for providing GIA data for this study. This research was done as part of Bringing Wetlands to Market, a NOAA-NERRS Collaborative and USGS-supported Project. This work was funded by the USGS Coastal \& Marine Geology Program with support from the USGS Land Change Science Program's LandCarbon program, and NSF Ocean Sciences Postdoctoral Fellowship (OCE-1323728). The National Ocean Mass Spectrometry facility at WHOI provided support for radiocarbon dating while WHOI Coastal Systems Group interns provided field and lab support. Any use of trade, firm, or product names is for descriptive purposes only and does not imply endorsement by the U.S. Government.

\section{Appendix A. Supplementary data}

Supplementary data to this article can be found online at https:// doi.org/10.1016/j.ecss.2018.11.003.

\section{References}

Alldred, M., Liberti, A., Baines, S.B., 2017. Impact of salinity and nutrients on salt marsh stability. Ecosphere 8, e02010. https://doi.org/10.1002/ecs2.2010.

Appleby, P.G., Oldfield, F., 1978. The calculation of lead-210 dates assuming a constant rate of supply of unsupported $210 \mathrm{~Pb}$ to the sediment. Catena $5,1-8$. https://doi.org/ 10.1016/S0341-8162(78)80002-2.

Balke, T., Stock, M., Jensen, K., Bouma, T.J., Kleyer, M., 2016. A global analysis of the seaward salt marsh extent: the importance of tidal range. Water Resour. Res. 52, 3775-3786. https://doi.org/10.1002/2015WR018318.

Barnhardt, W.A., Roland Gehrels, W., Kelley, J.T., 1995. Late Quaternary relative sealevel change in the western Gulf of Maine: evidence for a migrating glacial forebulge. Geology 23 (317). https://doi.org/10.1130/0091-7613(1995) $023<0317$ :LQRSLC > 2.3.CO;2.

Beckett, L.H., Baldwin, A.H., Kearney, M.S., 2016. Tidal Marshes across a Chesapeake Bay subestuary are not keeping up with sea-level rise. PloS One 11, e0159753. https:// doi.org/10.1371/journal.pone.0159753.

Benner, R., Fogel, M.L., Sprague, E.K., 1991. Diagenesis of belowground biomass of Spartina alterniflora in salt-marsh sediments. Limnol. Oceanogr. 36, 1358-1374. https://doi.org/10.4319/10.1991.36.7.1358.

Binford, M., 1990. Calculation and uncertainty analysis of 210Pb dates for PIRLA project lake sediment cores. J. Paleolimnol. 3. https://doi.org/10.1007/BF00219461.

Cahill, N., Kemp, A.C., Horton, B.P., Parnell, A.C., 2015. Modeling sea-level change using errors-in-variables integrated Gaussian processes. Ann. Appl. Stat. 9, 547-571. https://doi.org/10.1214/15-AOAS824.

Cahoon, D.R., Reed, D.J., Day, J.W., 1995. Estimating shallow subsidence in microtidal salt marshes of the southeastern United States: kaye and Barghoorn revisited. Mar. Geol. 128, 1-9. https://doi.org/10.1016/0025-3227(95)00087-F.

Chmura, G.L., 2013. What do we need to assess the sustainability of the tidal salt marsh carbon sink? Ocean Coast Manag. 83, 25-31. https://doi.org/10.1016/j.ocecoaman. 2011.09.006.

Chmura, G.L., Anisfeld, S.C., Cahoon, D.R., Lynch, J.C., 2003. Global carbon sequestration in tidal, saline wetland soils. Global Biogeochem. Cycles 17. https://doi.org/10. 1029/2002GB001917.

Crosby, S.C., Sax, D.F., Palmer, M.E., Booth, H.S., Deegan, L.A., Bertness, M.D., Leslie, H.M., 2016. Salt marsh persistence is threatened by predicted sea-level rise. Estuar. Coast Shelf Sci. 181, 93-99. https://doi.org/10.1016/j.ecss.2016.08.018.

Cutshall, N.H., Larsen, I.L., Olsen, C.R., 1983. Direct analysis of $210 \mathrm{~Pb}$ in sediment samples: self-absorption corrections. Nucl. Instrum. Methods Phys. Res. 206, 309-312. https://doi.org/10.1016/0167-5087(83)91273-5.

Davis, J., Currin, C., Morris, J.T., 2017. Impacts of fertilization and tidal inundation on elevation change in microtidal, low relief salt marshes. Estuar. Coast 40, 1677-1687. https://doi.org/10.1007/s12237-017-0251-0.

Day, J.W., Kemp, G.P., Reed, D.J., Cahoon, D.R., Boumans, R.M., Suhayda, J.M., Gambrell, R., 2011. Vegetation death and rapid loss of surface elevation in two contrasting Mississippi delta salt marshes: the role of sedimentation, autocompaction and sea-level rise. Ecol. Eng. 37, 229-240. https://doi.org/10.1016/j.ecoleng.2010. 11.021.

Deegan, L.A., Johnson, D.S., Warren, R.S., Peterson, B.J., Fleeger, J.W., Fagherazzi, S., Wollheim, W.M., 2012. Coastal eutrophication as a driver of salt marsh loss. Nature 490, 388-392. https://doi.org/10.1038/nature11533.

Dey, D., Ghosh, S.K., Mallick, B.K. (Eds.), 2000. Generalized Linear Models: a Bayesian Perspective Biostatistics. Marcel Dekker, New York.

Donnelly, J.P., 2006. A revised late Holocene sea-Level lecord for northern Massachusetts, USA. J. Coast Res. 225, 1051-1061. https://doi.org/10.2112/04-0207.1.

Donnelly, J.P., Bertness, M.D., 2001. Rapid shoreward encroachment of salt marsh cordgrass in response to accelerated sea-level rise. Proc. Natl. Acad. Sci. Unit. States Am. 98, 14218-14223. https://doi.org/10.1073/pnas.251209298.

Edwards, R.J., Wright, A.J., van de Plassche, O., 2004. Surface distributions of salt-marsh foraminifera from Connecticut, USA: modern analogues for high-resolution sea level studies. Mar. Micropaleontol. 51, 1-21. https://doi.org/10.1016/j.marmicro.2003. 08.002.

Engelhart, S.E., Horton, B.P., 2012. Holocene sea level database for the Atlantic coast of the United States. Quat. Sci. Rev. 54, 12-25. https://doi.org/10.1016/j.quascirev. 2011.09.013.

Engelhart, S.E., Horton, B.P., Douglas, B.C., Peltier, W.R., Tornqvist, T.E., 2009. Spatial variability of late Holocene and 20th century sea-level rise along the Atlantic coast of the United States. Geology 37, 1115-1118. https://doi.org/10.1130/G30360A.1.

Engelhart, S.E., Peltier, W.R., Horton, B.P., 2011. Holocene relative sea-level changes and glacial isostatic adjustment of the U.S. Atlantic coast. Geology 39, 751-754. https:// doi.org/10.1130/G31857.1.

Fox, L., Valiela, I., Kinney, E.L., 2012. Vegetation cover and elevation in long-term experimental nutrient-enrichment plots in Great Sippewissett Salt Marsh, Cape Cod, Massachusetts: implications fore and sea level rise. Estuar. Coast 35, 445-458. https://doi.org/10.1007/s12237-012-9479-x.

Ganju, N.K., Defne, Z., Kirwan, M.L., Fagherazzi, S., D'Alpaos, A., Carniello, L., 2017. Spatially integrative metrics reveal hidden vulnerability of microtidal salt marshes. Nat. Commun. 8, 14156. https://doi.org/10.1038/ncomms14156.

Gedan, K.B., Silliman, B.R., Bertness, M.D., 2009. Centuries of human-driven change in salt marsh ecosystems. Annu. Rev. Mar. Sci. 1, 117-141. https://doi.org/10.1146/ annurev.marine.010908.163930.

Gonneea, M., Kroeger, K., O'Keefe-Suttles, J., 2018. Collection, Analysis, and Age-dating of Sediment Cores from Salt Marshes on the South Shore of Cape Cod, Massachusetts, from 2013 through 2014. https://doi.org/10.5066/F7H41QPP.

Gutierrez, B., Uchupi, E., Driscoll, N., Aubrey, D., 2003. Relative sea-level rise and the development of valley-fill and shallow-water sequences in Nantucket Sound, Massachusetts. Mar. Geol. 193, 295-314. https://doi.org/10.1016/S0025-3227(02) 00665-5.

Hanson, A., Johnson, R., Wigand, C., Oczkowski, A., Davey, E., Markham, E., 2016. Responses of Spartina alterniflora to multiple stressors: changing precipitation patterns, accelerated sea level rise, and nutrient enrichment. Estuar. Coast 39, 1376-1385. https://doi.org/10.1007/s12237-016-0090-4.

Hawkes, A.D., Kemp, A.C., Donnelly, J.P., Horton, B.P., Peltier, W.R., Cahill, N., Hill, D.F., Ashe, E., Alexander, C.R., 2016. Relative sea-level change in northeastern Florida (USA) during the last $\sim 8.0$ ka. Quat. Sci. Rev. 142, 90-101. https://doi.org/10. 1016/j.quascirev.2016.04.016.

Hodson, R.E., Christian, R.R., Maccubbin, A.E., 1984. Lignocellulose and lignin in the salt marsh grass Spartina alterniflora: initial concentrations and short-term, post-depositional changes in detrital matter. Mar. Biol. 81, 1-7. https://doi.org/10.1007/ BF00397619.

Holmquist, J., Windham-Myers, L., Bernal, B., Byrd, K.B., Crooks, S., Gonneea, M.E. Herold, N., Knox, S.H., Kroeger, K., McCombs, J., Megonigal, J.P., Meng, L., Morris, J.T., Sutton-Grier, A.E., Troxler, T.G., Weller, D., 2018a. Uncertainty in United States coastal wetland greenhouse gas inventorying. Environ. Res. Lett. https://doi.org/10. 1088/1748-9326/aae157.

Holmquist, J.R., Windham-Myers, L., Bliss, N., Crooks, S., Morris, J.T., Megonigal, J.P., Troxler, T., Weller, D., Callaway, J., Drexler, J., Ferner, M.C., Gonneea, M.E., Kroeger, K.D., Schile-Beers, L., Woo, I., Buffington, K., Breithaupt, J., Boyd, B.M., Brown, L.N., Dix, N., Hice, L., Horton, B.P., MacDonald, G.M., Moyer, R.P., Reay, W., Shaw, T., Smith, E., Smoak, J.M., Sommerfield, C., Thorne, K., Velinsky, D., Watson, E., Grimes, K.W., Woodrey, M., 2018b. Accuracy and precision of tidal wetland soil carbon mapping in the conterminous United States. Sci. Rep. 8. https://doi.org/10. 1038/s41598-018-26948-7.

IPCC, 2014. Climate Change 2014: Synthesis Report. Intergovernmental Panel on Climate Change, Geneva, Switzerland.

Kearney, M.S., Turner, R.E., 2016. Microtidal marshes: can these widespread and fragile marshes survive increasing climate-sea level variability and human action? J. Coast Res. 319, 686-699. https://doi.org/10.2112/JCOASTRES-D-15-00069.1.

Kemp, A.C., Dutton, A., Raymo, M.E., 2015. Paleo constraints on future sea-level rise. Curr. Clim. Change Rep. 1, 205-215. https://doi.org/10.1007/s40641-015-0014-6.

Kemp, A.C., Hill, T.D., Vane, C.H., Cahill, N., Orton, P.M., Talke, S.A., Parnell, A.C., Sanborn, K., Hartig, E.K., 2017. Relative sea-level trends in New York City during the past 1500 years. Holocene 27, 1169-1186. https://doi.org/10.1177/ 0959683616683263.

Kirwan, M., Temmerman, S., 2009. Coastal marsh response to historical and future sealevel acceleration. Quat. Sci. Rev. 28, 1801-1808. https://doi.org/10.1016/j. quascirev.2009.02.022.

Kirwan, M.L., Guntenspergen, G.R., 2012. Feedbacks between inundation, root production, and shoot growth in a rapidly submerging brackish marsh: marsh root growth under sea level rise. J. Ecol. 100, 764-770. https://doi.org/10.1111/j.1365-2745. 2012.01957.x.

Kirwan, M.L., Mudd, S.M., 2012. Response of salt-marsh carbon accumulation to climate change. Nature 489, 550-553. https://doi.org/10.1038/nature11440.

Kirwan, M.L., Megonigal, J.P., 2013. Tidal wetland stability in the face of human impacts and sea-level rise. Nature 504, 53-60. https://doi.org/10.1038/nature12856.

Kirwan, M.L., Temmerman, S., Skeehan, E.E., Guntenspergen, G.R., Fagherazzi, S., 2016a. Overestimation of marsh vulnerability to sea level rise. Nat. Clim. Change 6, 253-260. https://doi.org/10.1038/nclimate2909.

Kirwan, M.L., Walters, D.C., Reay, W.G., Carr, J.A., 2016b. Sea level driven marsh expansion in a coupled model of marsh erosion and migration. Geophys. Res. Lett. 43, 4366-4373. https://doi.org/10.1002/2016GL068507.

Kolker, A.S., Goodbred, S.L., Hameed, S., Cochran, J.K., 2009. High-resolution records of the response of coastal wetland systems to long-term and short-term sea-level variability. Estuar. Coast Shelf Sci. 84, 493-508. https://doi.org/10.1016/j.ecss 2009.06.030.

Kroeger, K.D., Crooks, S., Moseman-Valtierra, S., Tang, J., 2017. Restoring tides to reduce 
methane emissions in impounded wetlands: a new and potent Blue Carbon climate change intervention. Sci. Rep. 7. https://doi.org/10.1038/s41598-017-12138-4.

Kulawardhana, R.W., Feagin, R.A., Popescu, S.C., Boutton, T.W., Yeager, K.M., Bianchi, T.S., 2015. The role of elevation, relative sea-level history and vegetation transition in determining carbon distribution in Spartina alterniflora dominated salt marshes. Estuar. Coast Shelf Sci. 154, 48-57. https://doi.org/10.1016/j.ecss.2014.12.032.

Langley, A.J., Mozdzer, T.J., Shepard, K.A., Hagerty, S.B., Patrick Megonigal, J., 2013. Tidal marsh plant responses to elevated CO2, nitrogen fertilization, and sea level rise. Global Change Biol. 19, 1495-1503. https://doi.org/10.1111/gcb.12147.

Maio, C.V., Gontz, A.M., Weidman, C.R., Donnelly, J.P., 2014. Late Holocene marine transgression and the drowning of a coastal forest: lessons from the past, Cape Cod, Massachusetts, USA. Palaeogeogr. Palaeoclimatol. Palaeoecol. 393, 146-158. https:// doi.org/10.1016/j.palaeo.2013.11.018.

Mariotti, G., 2016. Revisiting salt marsh resilience to sea level rise: are ponds responsible for permanent land loss? J. Geophys. Res. Earth Surf. 121, 1391-1407. https://doi. org/10.1002/2016JF003900.

Morgan, P.A., Burdick, D.M., Short, F.T., 2009. The functions and values of fringing salt marshes in northern New England, USA. Estuar. Coast 32, 483-495. https://doi.org/ 10.1007/s12237-009-9145-0.

Morris, J.T., Barber, D.C., Callaway, J.C., Chambers, R., Hagen, S.C., Hopkinson, C.S., Johnson, B.J., Megonigal, P., Neubauer, S.C., Troxler, T., Wigand, C., 2016. Contributions of organic and inorganic matter to sediment volume and accretion in tidal wetlands at steady state: sediment bulk density and ignition loss. Earths Future 4, 110-121. https://doi.org/10.1002/2015EF000334.

Morris, J.T., Bowden, W.B., 1986. A mechanistic, numerical model of sedimentation, mineralization, and decomposition for marsh Sediments1. Soil Sci. Soc. Am. J. 50, 96. https://doi.org/10.2136/sssaj1986.03615995005000010019x.

Morris, J.T., Sundareshwar, P.V., Nietch, C.T., Kjerfve, B., Cahoon, D.R., 2002. Responses of coastal wetlands to rising sea level. Ecology 83, 2869-2877. https://doi.org/10. 1890/0012-9658(2002)083[2869:ROCWTR]2.0.CO;2.

Moseman-Valtierra, S., Abdul-Aziz, O.I., Tang, J., Ishtiaq, K.S., Morkeski, K., Mora, J., Quinn, R.K., Martin, R.M., Egan, K., Brannon, E.Q., Carey, J., Kroeger, K.D., 2016. Carbon dioxide fluxes reflect plant zonation and belowground biomass in a coastal marsh. Ecosphere 7, e01560. https://doi.org/10.1002/ecs2.1560.

Narayan, S., Beck, M.W., Wilson, P., Thomas, C.J., Guerrero, A., Shepard, C.C., Reguero, B.G., Franco, G., Ingram, J.C., Trespalacios, D., 2017. The value of coastal wetlands for flood damage reduction in the Northeastern USA. Sci. Rep. 7. https://doi.org/10. 1038/s41598-017-09269-z.

Nerem, R.S., Beckley, B.D., Fasullo, J.T., Hamlington, B.D., Masters, D., Mitchum, G.T., 2018. Climate-change-driven accelerated sea-level rise detected in the altimeter era. Proc. Natl. Acad. Sci. Unit. States Am. 115, 2022-2025. https://doi.org/10.1073/ pnas.1717312115.

Neubauer, S.C., 2008. Contributions of mineral and organic components to tidal freshwater marsh accretion. Estuar. Coast Shelf Sci. 78, 78-88. https://doi.org/10.1016/j. ecss.2007.11.011.

Niering, W.A., Warren, R.S., Weymouth, C.G., 1977. Our dynamic tidal marshes: vegetation changes as revealed by peat analysis. Conn. Arbor. Bull. 22, 12

NOAA, 2003. Computational Techniques for Tidal Datums Handbook. NOAA special publication NOS CO-OPS 2. General Books LLC.

NOAA National Estuarine Research Reserve System (NERRS), 2017. System-wide monitoring program. Data accessed from the NOAA NERRS Centralized Data Management Office website. http://www.nerrsdata.org/.

Nyman, J.A., Walters, R.J., Delaune, R.D., Patrick, W.H., 2006. Marsh vertical accretion via vegetative growth. Estuar. Coast Shelf Sci. 69, 370-380. https://doi.org/10. 1016/j.ecss.2006.05.041.

Oldale, R.N., 1992. Cape Cod and the Islands: the Geologic Story. Parnassus Imprints 208 pages.

Orson, R.A., Howes, B.L., 1992. Salt marsh development studies at Waquoit Bay, Massachusetts: influence of geomorphology on long-term plant community structure. Estuar. Coast Shelf Sci. 35, 453-471. https://doi.org/10.1016/S0272-7714(05) 80025-3.

Peltier, W.R., Argus, D.F., Drummond, R., 2015. Space geodesy constrains ice age terminal deglaciation: the global ICE-6G_C (VM5a) model: global glacial isostatic adjustment. J. Geophys. Res. Solid Earth 120, 450-487. https://doi.org/10.1002/ 2014JB011176.

Raposa, K.B., Weber, R.L.J., Ekberg, M.C., Ferguson, W., 2017. Vegetation dynamics in Rhode Island salt marshes during a period of accelerating sea level rise and extreme sea level events. Estuar. Coast 40, 640-650. https://doi.org/10.1007/s12237-0150018-4.

Redfield, A.C., 1972. Development of a new England salt marsh. Ecol. Monogr. 42, 201-237. https://doi.org/10.2307/1942263.

Reimer, P.J., Baillie, M.G.L., Bard, E., Bayliss, A., Beck, J.W., Blackwell, P.G., Bronk Ramsey, C., Buck, C.E., Burr, G.S., Edwards, R.L., Friedrich, M., Grootes, P.M., Guilderson, T.P., Hajdas, I., Heaton, T.J., Hogg, A.G., Hughen, K.A., Kaiser, K.F., Kromer, B., McCormac, F.G., Manning, S.W., Reimer, R.W., Richards, D.A., Southon, J.R., Talamo, S., Turney, C.S.M., van der Plicht, J., Weyhenmeyer, C.E., 2009. IntCal09 and Marine09 radiocarbon age calibration curves, 0-50,000 years cal BP. Radiocarbon 51, 1111-1150. https://doi.org/10.1017/S0033822200034202.

Rietbroek, R., Brunnabend, S.-E., Kusche, J., Schröter, J., Dahle, C., 2016. Revisiting the contemporary sea-level budget on global and regional scales. Proc. Natl. Acad. Sci. Unit. States Am. 113, 1504-1509. https://doi.org/10.1073/pnas.1519132113.

Sallenger, A.H., Doran, K.S., Howd, P.A., 2012. Hotspot of accelerated sea-level rise on the Atlantic coast of North America. Nat. Clim. Change 2, 884-888. https://doi.org/ 10.1038/nclimate1597.

Shepard, C.C., Crain, C.M., Beck, M.W., 2011. The protective role of coastal marshes: a systematic review and meta-analysis. PloS One 6, e27374. https://doi.org/10.1371/ journal.pone.0027374.

Smith, S.M., 2015. Vegetation change in salt marshes of Cape Cod national seashore (Massachusetts, USA) between 1984 and 2013. Wetlands 35, 127-136. https://doi. org /10.1007/s13157-014-0601-7.

Tripathee, R., Schäfer, K.V.R., 2015. Above- and belowground biomass allocation in four dominant salt marsh species of the Eastern United States. Wetlands 35, 21-30. https://doi.org/10.1007/s13157-014-0589-z.

Turner, R.E., Swenson, E.M., Milan, C.S., 2002. Organic and inorganic contributions to vertical accretion in salt marsh sediments. In: Weinstein, M.P., Kreeger, D.A. (Eds.), Concepts and Controversies in Tidal Marsh Ecology. Kluwer Academic Publishers, Dordrecht, pp. 583-595. https://doi.org/10.1007/0-306-47534-0 27.

Uchupi, E., Giese, G.S., Aubrey, D.G., Kim, D.J., 1996. The late quaternary construction of Cape Cod, Massachusetts: a reconsideration of the W. M. Davis model. In: Special Paper 309: the Late Quaternary Construction of Cape Cod, Massachusetts: a Reconsideration of the W. M. Davis Model. Geological Society of America, pp. 1-69. https://doi.org/10.1130/0-8137-2309-4.1.

Valiela, I., Geist, M., McClelland, J., Tomasky, G., 2000. Nitrogen loading from watersheds to estuaries: verification of the Waquoit Bay nitrogen loading model. Biogeochemistry 49, 277-293. https://doi.org/10.1023/A:1006345024374.

Valiela, I., Owens, C., Elmstrom, E., Lloret, J., 2016. Eutrophication of Cape Cod estuaries: effect of decadal changes in global-driven atmospheric and local-scale wastewater nutrient loads. Mar. Pollut. Bull. 110, 309-315. https://doi.org/10.1016/j. marpolbul.2016.06.047.

Voss, C.M., Christian, R.R., Morris, J.T., 2013. Marsh macrophyte responses to inundation anticipate impacts of sea-level rise and indicate ongoing drowning of North Carolina marshes. Mar. Biol. 160, 181-194. https://doi.org/10.1007/s00227-012-2076-5.

van de Plassche, O. (Ed.), 1986. Sea-level Research. Springer Netherlands, Dordrecht. https://doi.org/10.1007/978-94-009-4215-8.

Watson, E.B., Andrews, H.M., Fischer, A., Cencer, M., Coiro, L., Kelley, S., Wigand, C., 2015. Growth and photosynthesis responses of two co-occurring marsh grasses to inundation and varied nutrients. Botany 93, 671-683. https://doi.org/10.1139/cjb2015-0055.

Watson, E.B., Wigand, C., Davey, E.W., Andrews, H.M., Bishop, J., Raposa, K.B., 2017 Wetland loss patterns and inundation-productivity relationships prognosticate widespread salt marsh loss for Southern New England. Estuar. Coast 40, 662-681. https://doi.org/10.1007/s12237-016-0069-1.

Weston, N.B., 2014. Declining sediments and rising Seas: an unfortunate convergence for tidal wetlands. Estuar. Coast 37, 1-23. https://doi.org/10.1007/s12237-013-9654-8.

Williams, C.K.I., Rasmussen, C.E., 1996. Gaussian processes for regression. In: Advances in Neural Information Processing Systems 8. MIT.

Woodroffe, S.A., Barlow, N.L.M., 2015. Reference water level and tidal datum. In: Shennan, I., Long, A.J., Horton, B.P. (Eds.), Handbook of Sea-level Research. John Wiley \& Sons, Ltd, Chichester, UK, pp. 171-180. https://doi.org/10.1002/ 9781118452547.ch11.

Yin, J., Schlesinger, M.E., Stouffer, R.J., 2009. Model projections of rapid sea-level rise on the northeast coast of the United States. Nat. Geosci. 2, 262-266. https://doi.org/10. 1038/ngeo462. 